\title{
Evaluation Program of the Appraisal List of Officers Personnel Assigned In the Indonesian Navy
}

\author{
${ }^{1}$ Aries Sudarso Sutarno*, ${ }^{2}$ R. Madhakomala, ${ }^{3}$ Suparno Eko Widodo
}

${ }^{1}$ Doctoral Program of HRM Department, Universitas Negeri Jakarta, Indonesia, Jl. Rawamangun Muka, Jakarta 13220, Indonesia

${ }^{2,3}$ Lectures at HRM Department, Universitas Negeri Jakarta, J1.Rawamangun Muka Jakarta 13220, Indonesia

\begin{abstract}
The purpose of this research is to find out the effectiveness of the Program of "Appraisal List of Officers Personnel Assigned in the Indonesian Navy (Dapen Persmil TNI AL)" at the Office of the Navy Personnel Service, Jl. Cilangkap Jakarta. Officers' assignments are not enough if they are not supported by the awareness of the leadership of the Navy to totally touch on human resources management, especially at Navy Officers and not merely a rhetoric. However, the implementation of the assignment of Navy officers experienced problems related to the attitude and behavior. Therefore, in reality the implementation of the program of Dapen Persmil is not in accordance with the career development program for the Navy personnel launched by the Armed Forces Commander in 2016 until 2017 in the Principal Commands of the TNI Commander's policy on enhancing the professionalism of soldiers through assignment, education and training, fulfillment of equipment, and soldier rights are managed with a good management system. Based on scientific literature, this research is a evaluation program study and the evaluation model. Data obtained through observation instruments, interviews, and documentation as well as using descriptive survey research methods, by means of explanotary and qualitative approaches. On the basis of the principle of model development, the effectiveness of the program, it is hoped that Navy Officers assigned to the Navy will no longer cause problems in their assignments but can develop skills and professionalism in order to improve work optimization.
\end{abstract}

Keywords: Human Resources Management, the Program of Dapen Persmil TNI AL, Evaluation Program, Indonesian National Army Navy.

\section{Introduction}

The Indonesian Navy is one of the main components of the Indonesian Armed Forces (TNI) branch of the army which has responsibility for the defense operations of the Republic of Indonesia at sea as mandated in Article 9 of Law Number 34 of 2004 concerning the TNI, Navy and Article 1 of the Regulation President Number 66 of 2019 concerning the Organizational Structure of the Indonesian National Armed Forces, the Navy which is reliable and respected in order to safeguard and secure and uphold the law and sovereignty at sea in Indonesia and be able to have a deterrent power in countries threatening sea sovereignty and Indonesian sovereignty. To realize the success of the tasks carried out by the Indonesian Navy is not easy without hard work and is supported by the success of the organization. According to experts, organizational critical factors are based on the ability of organizations to ensure the success of competitive performance results for individuals, groups or organizations and are supported by the concepts and logic of critical success factors in the form of a supply chain and logistics chain such as: communication, relationship development, standard setting, supervision (Pourhanifeh \& Mazdeh, 2016: 206) to hone their knowledge, skills, abilities, and attitudes to be productive in their own fields (Jalagat, Jr., 2017: 146).

(Bruns, 2014: 4) states that a recent study of HR changes in organizations is enforced by legal regulations, opportunities and threats to develop the role of strategic HR and effective HR policies and practices, namely the implementation of human resource management (HRM) as an approach strategic, integrated and coherent for the work, development and welfare of people working in organizations (Armstrong \& Taylor, 2019: 5). One way to enhance organizational innovation is through effective human resource management 
(HRM) practices to examine the direct relationship between HRM practices (Boon., Den Hartog, \& Lepak, 2019: 2) which covers performance appraisal, career management, training, reward systems, and recruitment and organizational innovation such as product innovation, process innovation, and administrative innovation in the face of rapid change (Tan \& Nasurdin, 2011; 155; Deloitte's Human Capital, 2019: 7). Human resource practices are a series of different but interrelated activities, functions and processes that are directed to attract, develop (Lado et al. In Narang, 2016: 1-2) and retain qualified personnel. Therefore, military organizations must strategically align human resource management with the overall strategy (Patrichi, 2015: 76)

According to the various descriptions of experts related to the understanding of human resources (HR) and human resource management (HRM), if implemented in the Navy's organization, the success of the Navy's duty is greatly influenced by the capabilities of its HR. In line with this view, the Indonesian Ministry of Defense 2008 stated that improving the quality and welfare of defense human resources (HR) is one of the main targets in addition to efforts to improve defense capabilities, rejuvenation and the addition of key weapons systems and enhancing technology and the domestic defense industry (Warsono, Budiyanto, Riduwan, 2018: 449). The complexity of the assignment challenges faced by the Navy has an impact on the readiness of the profile of TNI personnel in carrying out their duties. The profile of TNI personnel has the quality and ability to carry out each of their duties in a professional manner and keep abreast of developments and changes in the assignment environment. Qualified TNI personnel are not only on duty within the Indonesian Navy, but based on Indonesian Law Number 34 of 2004 concerning the Indonesian National Army can also serve in the Ministries and Non-Ministries.

Whereas the understanding of the assignment of Navy personnel is to utilize personnel in the context of serving within the Navy to safeguard the sovereignty of the territorial sea of the Republic of Indonesia (NKRI) in accordance with what is mandated by the Law. The assignment of personnel consisting of Officers, Bintara and Tamtama is an important matter which is also supported by government policy so that it can be realized in the Navy's real organization. The assignment of TNI AL officers is directed towards realizing officers who are capable of acting as leaders, thinkers, initiators, determinants and persons responsible for the success of the Navy's mission. Navy officers have roles and functions as commanders, leaders, teachers, coaches and fathers who are always aware and aware of their calling. In totality, the leadership is to color the Navy as a whole, both quality, effectiveness, efficiency and personality for the scope of the assignment within and in the organization of the Indonesian Navy.

Officers' assignments are not enough if they are not supported by the awareness of the leadership of the Navy to totally touch on the management of human resources (HR), especially at Navy Officers and not merely a rhetoric. However, the implementation of the assignment of Navy officers experienced problems regarding the increase in officers' problems related to the attitude and behavior problems that carried out the assignment. This view is in line with (Jalagat, Jr., 2017: 146) which states that leading and managing people has an important role for the organization and especially for workers related to changes that enable them to hone their knowledge, skills, abilities, and attitudes to be productive in their own fields as well as these changes encourage organizational productivity and profitability In the case of officers' behavior problems in the assignment within the Navy based on data obtained from the sources "Coordination Meeting of the Navy Personnel in 2016, 2017 and 2018" indicates that there has been an increase in the number of personnel violations since 2016, a number of 115 violations, then in 2017 found 551 violations. But in 2018 there is a tendency to decrease in terms of the number of violations by officers, which is 238 cases. In this study, researchers obtained data and described the problems of Officer Personnel in the assignment of the Navy environment from 2016 to 2018 as follows:

Table 1: Data on Officer Personnel Issues in Assignments within the Navy of the Year. 2016 - 2018 After the Implementation of the Appraisal List of Officers Personnel Assigned in the Indonesian Navy (Dapen Persmil TNI AL) Program 


\begin{tabular}{|l|l|l|l|l|}
\hline \multirow{2}{*}{ No } & \multirow{2}{*}{ Type of Violation } & \multicolumn{3}{|l|}{ Number of Violations } \\
\cline { 3 - 5 } & & In 2016 & In 2017 & In 2018 \\
\hline 1. & Abuse & 16 & 409 & 15 \\
\hline 2. & Authority & - & - & - \\
\hline 3. & Lying Investment & 70 & 57 & 38 \\
\hline 4. & Desertion & 8 & 7 & 7 \\
\hline 5. & Immoral & 13 & 66 & 127 \\
\hline 6. & Be absent & 1 & 5 & 9 \\
\hline 7. & Drugs & 7 & 7 & 18 \\
\hline
\end{tabular}

Source: Processed from the Results of the 2016 and 2018 Indonesian Navy Personnel Coordination Meeting

Based on table 1 it can be seen that there has been an increase in personnel behavior problems that can have quite serious consequences on the assignment of Navy personnel. This becomes incompatible with the career development program for the Navy personnel launched by the TNI Commander in 2016 to 2017 in the TNI Commander's Policy Principles on enhancing soldier professionalism through assignments, education and training, fulfilling equipment, and soldier rights managed by good management system. According to the TNI Commander Regulation Number Perpang / 59 / X / 2008 which mandates that the implementation of the assignment can be realized through the management system of career guidance of personnel of the TNI appropriately, steadily, objectively by developing and utilizing each soldier as well as possible in order to obtain useful results and power optimal use.

Referring to the TNI Commander's Regulation, it can be interpreted that the understanding of the assignment is an important part of the personnel to be used and utilized by the Navy organization. However, due to the problem of Officer Personnel in the assignment of the Navy environment, the organization is certainly not able to run optimally in terms of assigning personnel within the Navy in an effort to increase the professionalism of soldiers through assignments, According to (Army Regulation 600-100 Personnel-2017: 1 -2), the understanding of warriors can be interpreted as a respectable profession, possessing military expertise, and esprit de corps who are brave, have professional competence and leaders who have knowledge coverage in four main areas: (1) human and leader development, (2) expertise moral-ethical, (3) tactical, (4) technical, and (4) geo-cultural and political.

Then, performance appraisal of soldiers can be done through a better assessment of the potential of soldiers as individuals and provides a means for various human resource decisions, including promotion, training, and personnel assignments (Evans \& Robinson, 2020: 90). On the other hand, these efforts certainly require significant investment to develop soldier's knowledge, skills, attributes, behavior to enhance the potential and professionalism of soldiers (U.S. Army Noncommissioned Officer Professional Development Guide, 2018: 3). According to (Evans \& Bae, 2018: 1), a formal performance appraisal system is an officer evaluation report that is used to assess officers in five domains: physical quality, intelligence, leadership, personal quality, and general value for services as well as for reaching personnel decisions objective to improve employee performance (Ayomikun O, 2017: 16), According to (Idowu, 2017: 15), the employee evaluation process is related to employee performance which is the main focus of human resource managers to achieve organizational goals through superior employee performance ( Chen and Eldridge, 2012).

Noting the concept of the relationship between appraisal and performance, the appraisal currently in use has problems because the program of Dapen Pesmil TNI AL only stops at the officers' performance. Normatively this program has not touched efforts to control how officers do their work by controlling behavior in the assignment within the program of Dapen Pesmil TNI AL. As a result, the program was not 
optimal in its implementation so it affected the increase in violations of the officers' behaviors that had gained positions within the Navy Officer after the program of Dapen Pesmil TNI AL was implemented.

On the other hand in the scope of the substance of the assessment as questioned above, it can be interpreted as an indicator of unsuccessful assignment of Navy officers in the Armed Forces, TNI Headquarters and agencies outside the Navy. According to the TNI Perpang Perpang Number 59 / X / 2008, that the policy of assigning Indonesian Navy (TNI AL) officers was determined not only by the policy makers of the TNI Headquarters as users and formulating policies for the field of TNI personnel in the field, but also involving the TNI AL Headquarters as well as formulating, and implementing operational policies in his role as a personnel builder. Therefore, in order to determine the existence of the Indonesia Navy in the future and refer to the 2017 Navy Chief of Staff Policy in the field of personnel, the assignment was held selectively with a merit system. One of the ways to implement the merit system in the Navy is to use an officer appraisal program (Dapen Persmil TNI AL) to be used in assessing officers who will and are on duty within the Navy. The affirmation of the personnel assessment program has also been established in the Indonesian Navy Strategic Plan until 2024. In this regard, the optimal implementation of career development as a macro aspect and synergizing it with micro aspects both in quantity and quality to meet organizational needs is a must. The assignment device for the Indonesian Navy personnel is the Appraisal List (Dapen Persmil TNI AL) which is a tool or tool in the formation of Navy personnel.

From the various explanations that have been stated above, the object of the evaluation of the personnel evaluation program is the assessment of the Navy Navy Dapen, which is to assess the officers serving in the Navy environment. In this case, the researcher found that the limitations of previous research specifically examining the Navy Navy Dapen program so that more in-depth studies of the program and the factors used in assessing it were necessary, so that the current program could be continued by improving and increase it. The object of the evaluation of the program of Dapen Persmil TNI AL is how the behavior of the Indonesian Navy Officers assigned to the Navy environment no longer causes problems in their assignments. Then, based on the conceptual framework of the thought, the researcher is interested in researching with an evaluation approach on " The Appraisal List of Officers Personnel Assigned in the Indonesian Navy (Dapen Persmil TNI AL)"

\section{Research Methodology}

The method or approach to be taken to provide answers to research problems (Santoso, 2017), and the method chosen in this study is an evaluation study of the program of Dapen Persmil TNI AL. The evaluation model chosen was a combination of the Provus Discrepancy Evalution Model and the Kickpatrick Evaluation Model (Level 3, Behavior and Level 4, Results). The application of the method is done by survey research, namely: research that relies on the use of in-depth interviews with structured questions, and document analysis. Data obtained through observation instruments, interviews, and documentation as well as using descriptive survey research methods, by means of explanotary and qualitative approaches. The Navy's Dapen Persmil program evaluation research design model is depicted in the Provus discrepancy evaluation model (DEM) design, and the Kirkpatrick evaluation model is limited (Philips, Jack.J \& Ron Drewstone, 2000: 122)), namely Level 3 (Behavior) \& level 4 (Results) shown in the picture as follows: 


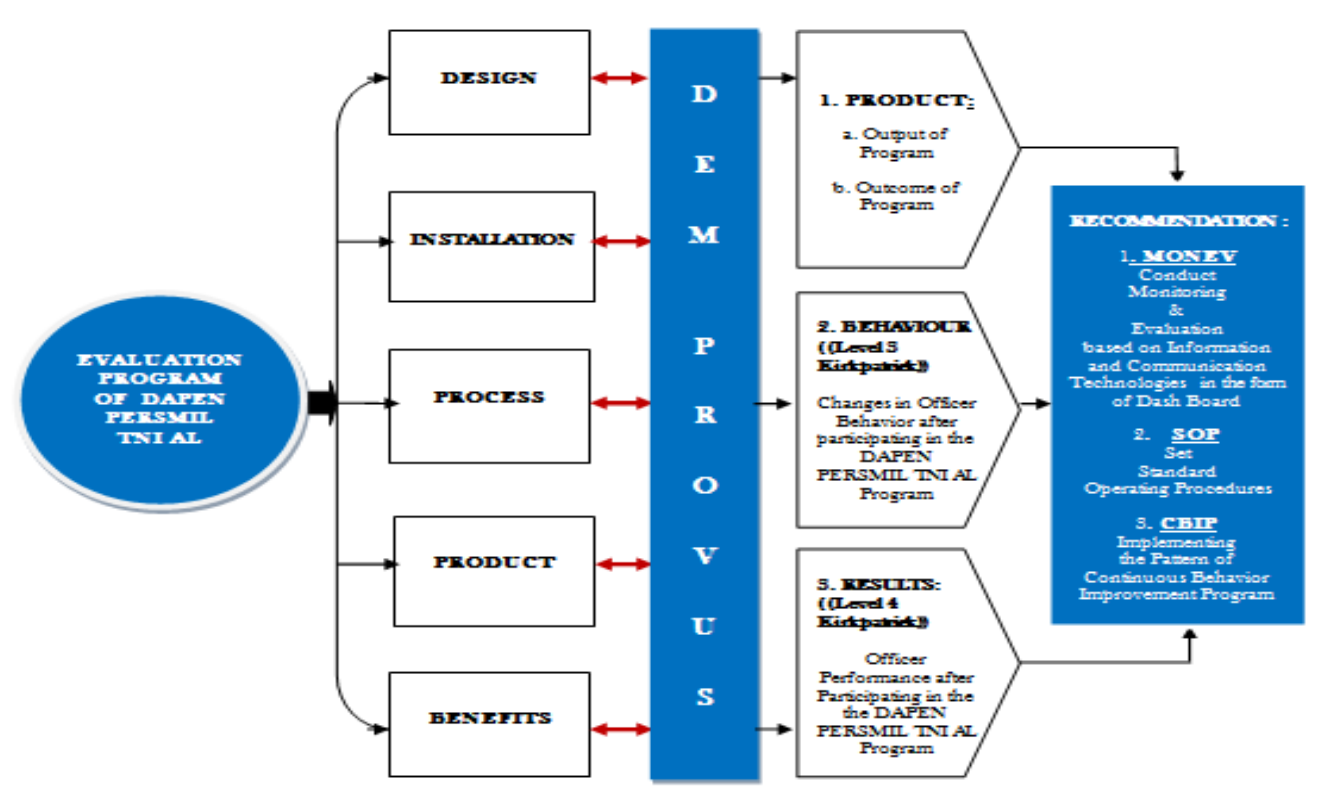

\section{Figure 1 : Provus Discrepancy Evaluation Model (DEM) Research Design Model, and Level 3 \& Level 4 Kirkpatrick Evaluation Model ((Philips, Jack.J \& Ron Drewstone, 2000: 122))*}

- Data obtained through observation instruments, interviews, documentation and using descriptive survey research methods, by way of explanotary and qualitative approaches.

\section{Discussion \& Research Results}

The signal that there is still a moral violation by Indonesian Navy Officers in the Navy assignment environment, implies the emergence of large costs because to form someone to become an Officer in the Navy is not cheap. In this case, the researcher conducted an empirical study related to the problems of Navy Officers in the field of assignment to be immediately addressed given the availability of regulations or policies to eliminate this problem including the program of Dapen Persmil TNI AL has not been able to solve the real root of the problem. The implementation of the program of Dapen Persmil TNI AL tends to be limited to administrative processes and has not been able to touch and change the officers' behavior. Signs related to an increase in violations committed by Navy Officers assigned to the Indonesian Navy after the implementation of the program of Dapen was the focus of this study. The findings of the researchers, regarding the level of problems that occur are still low moral aspects in fostering officers who are assessed / subordinate. This is as a field finding that the existence of the program of Dapen Persmil TNI has not had a positive impact in fostering Navy Officers.

The results of the analysis conducted by researchers at this time can be an understanding, this is in line with what the results of research experts, which states that program evaluation is a systematic investigative activity about something that is valuable and valuable from an object (Muryadi, 2017: 3) in order to assess work performance and how to perfect the next program (Prayogo, 2011: 44). Then, for issues of objectivity, neutrality, validity, and reliability are the same as academic research because the evaluation results must be objective so that they are valid as a basis for further program policies (Prayogo, 2011: 45). Furthermore, it can be interpreted that the evaluation results are usually obtained about the attributes or the properties contained in the individual or object concerned. In addition to using tests, data can also be collected using questionnaires, observations, and interviews or other appropriate forms of instruments. According to Arikunto (2012: 36-37), evaluation is the activity of collecting data or information to be compared with criteria, and to draw conclusions which are the results or findings of evaluation (Owen in Munthe, 2015: 2).

According to Guyadeen \& Seasons (2016: 2), experts state that in the public sector (Wholey, Hatry \& Newcomer, 2010: 6), evaluation plays an important role in the process of policy making, planning and identifying areas for improvement (Pal, 2014) that aims to synthesize information about the assessment of the degree of conformity between desired and undesirable outcomes (McDavid and Hawthorn, 2006) and the cost effectiveness of programs and plans as a form of political accountability or legislative reasons, to show 
the benefits of their actions to the public (Vedung 2010). According to (Durning and Hemmer in Frye and Hemmer, 2012: 134), program evaluation is about understanding a program through information gathering (Munthe, 2015: 3) that is routine, systematic, and intentional to uncover and or identify what is contributing to the success of the program as well as what actions need to be taken to overcome the problem of the findings. While the purpose of research evaluation is to collect, analyze, and present useful information about the object of evaluation, assess it by comparing it with evaluation indicators and the results are used to make decisions about the object being evaluated (Wirawan (2016: 7)

Thus, the evaluation of the implementation of the program of Dapen Persmil TNI AL within the Navy assignment environment can be interpreted as a series of resources and activities directed at one or more common goals in order to achieve certain results as the implementation of actions to realize a decrease in officers' moral violations such as: the occurrence of immorality, trafficking drugs and abuse of authority within the Navy assignment. In this context, ethical leadership and work skills become a strategic agenda to be initiated in the implementation of the program of Dapen Persmil TNI AL because both are considered equally important in determining one's competence and suitability for work (Paine, 2020, Harvard Business Review https://hbr.org/ 1994/03 / managing-for-organizational-integrity, accessed March 20, 2020). Ethical leadership rests on two precepts. First, leaders behave morally when they carry out their role; and second, leaders shape the ethical context of their groups and organizations. (Johnson, 2007) in (Chang \& Davis, 2017: 37).

\section{Research Instruments, Techniques and Data Collection Procedures}

The research instrument was in the form of a questionnaire before being used in collecting validation data, which was tested on respondents who had characteristics as the sample of this study. Validation is done by expert validation and empirical validation. According to (Sugiono, 2016) to test the validation of the instrument can be used experts / experts (judgment experts). The instrument validation is used by officers or personnel of the Indonesian Navy who have expertise in the field of personnel by examining the instrument's eligibility regarding the substance and in accordance with the practice within the Navy"s assignmnet. This research was oriented to the quality of the program to be valuable information in making decisions to improve the assessment of officers serving in the Indonesian Navy, the data collection techniques and procedures used in this evaluation study are sourced from primary data and secondary data. Primary data is data that takes place originating from the chairperson and members of the Kotama Unit Personnel Office, the Head of the Kotama Personnel Agency Personnel Service Office, the Appraisal Unit and the assessed Officer. While the secondary data is data taken from existing data in the form of assessment management guidelines. Data collection in this study uses several data collection techniques, namely observation, interviews, questionnaires and documentation studies.

Then, researchers have placed various informants, and used triangulation techniques to test validation in terms of collecting data using two types of triangulation, namely triangulation of data, and triangulation of investigators as follows: First, triangulation of data is a data representation combined from various sources and in time different, different places, and come from different people (Denzin, 1978) in (Flick, von Kardorff, \& Steinke, 2004: 179-183; Flick, 2006: 444) in order to deepen and broaden understanding of conceptual frameworks or to better describe or explain the richness and complexity of human behavior from various perspectives (Cohen \& Manion, 2007). In this case, researchers also use methodological triangulation, namely the use of more than one option to collect data, such as in-depth interviews, observations, questionnaires, and documents (Kennedy, 2009) for the same data source and case simultaneously (Sugiyono, 2013: 330 -331). Second, triangulation of investigators is to use interviewers or other observers to balance the influence of the subjectivity of the researcher (Denzin, 1978) in (Flick, von Kardorff, \& Steinke, 2004: 179-183; Flick, 2006: 444) with the aim of obtaining data from sources different with the same technique (Sugiyono, 2013: 330-331). This can be described as follows: 


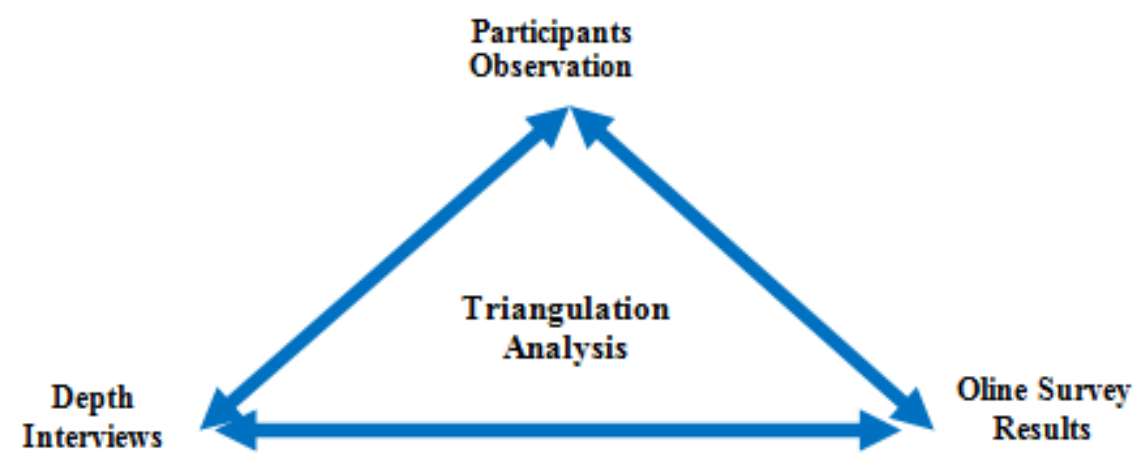

Figure 2 : Three Types of Triangulating For Minimize Bias (Cohen \& Manion, 2007)

In accordance with the model used, the discrepancy evluation model (DEM) 1, the steps of doing this research can be seen in Figure 2.6, the comparison process at all stages in DEM is illustrated (Rahman, Affandi, \& Matore, 2018: 51 - 52) as follows:

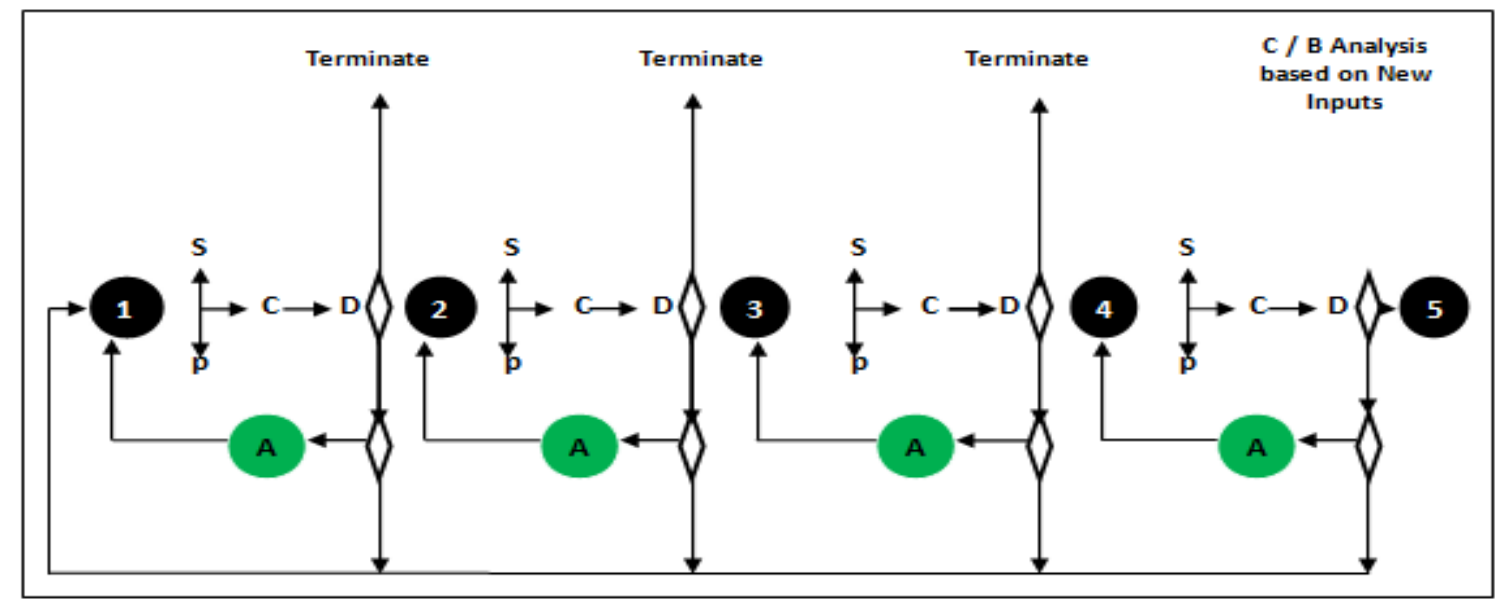

Figure 3: Theoretical Framework in DEM (Provus, 1969)

Based on Figure 4, DEM can be considered as an ongoing cycle, S (Standard), representing Standards; P (Performance) is Performance; C (Compare) is an indication to compare; D (Discrepancy) is an abbreviation for information Mismatch; and A (Alteration) signifies a change in either the standard or program performance. Figures 1 to 5 refer to Stages I to V which describe the various stages of evaluation in a DEM. After obtaining difference information ((Discrepancy - D), the program manager is left with four possible decisions (Provus, 1969). The first possible decision is that the program can proceed to the next level when there is no difference information. However, if a discrepancy arises, three options that may be available for program managers to ponder: to recycle certain stages after modification, to recycle to Phase I after modification, or to stop the program according to (Kirkpatrick, 1998 in Ikramina \& Gustomo, 2014: 103), to ascertain whether training programs succeed in achieving the objectives, training evaluation is needed, namely the process of gathering information and data systematically which includes training plans, goals and objectives to be obtained by the company, training program results, feedback, including participant reactions, participant learning outcomes, changes in participant behavior in workplace, and the results obtained, namely: Leve 13 (Behavior) and Level 4 (Results).

Level 3 (Behavior) aims to evaluate how far participants have changed behavior (Kirkpatrick, 1998 in Nurhayati, 2018: 175), based on the training received because it is important to realize that behavior can only change if conditions are favorable and this stage is best measured after two the above level is carried out, and level 4 (Outcomes) aims to analyze the final results of the training (Kirkpatrick, 2006,134 in Nurhayati, 2018: 176), the results determined by the company to be good for the business, good for employees, or good for the bottom line (Ikramina \& Gustomo, 2014: 103). The reason is because the Disrepancy Evaluation Model (DEM) is significant enough to assess whether in the implementation of the Staff Officers Appraisal List Checklist within the Navy there is a mismatch between the program standards 
set and the results achieved and the Kirkpatrick Level 3 (Behavior) and Level 4 (Behavior) and Level 4 (Results) are used to search for and find improvement in behavior (improvement behavior) after participating in the Personnel Assessment Program for Officers Assigned to the Navy which is a performance evaluation (performance evaluation). Researchers' findings regarding the situation and living conditions of officers within the Navy in general influenced by the social structure and culture of the population in the community.

Thus, the evaluation criteria that the researchers used as a guideline to measure the achievement of the program of Dapen Persmil TNI AL were assigned to the Navy environment based on predetermined indicators. The criteria that researchers set as well as guidelines in evaluating the program in order to produce research results that can be accounted for because of the following benchmarks:

\section{Grids of the Success Criteria of Design Evaluation}

Table 2: Grids of The Success Criteria of Design Evaluation

\begin{tabular}{|c|c|c|c|}
\hline $\begin{array}{l}\text { Evaluatio } \\
\text { n Stages }\end{array}$ & $\begin{array}{l}\text { Sub } \\
\text { focus }\end{array}$ & Evaluated Aspects & $\begin{array}{l}\text { The } \\
\text { Success } \\
\text { Criteria }\end{array}$ \\
\hline \multirow[t]{2}{*}{ Design } & \multirow[t]{2}{*}{$\begin{array}{l}\text { Standa } \\
\text { rd } \\
\text { Design } \\
\text { Criteri } \\
\text { a }\end{array}$} & $\begin{array}{l}\text { I. Program foundation policies : } \\
\text { 1. Law Number } 04 \text { of } 2004 \text { concerning the TNI; } \\
\text { 2. Presidential Regulation No. } 39 \text { concerning the } \\
\text { Administration of TNI Soldiers; } \\
\text { 3. Regulation of the TNI Commander no regarding Use of } \\
\text { TNI Personnel; } \\
\text { 4. Decree of the Minister of Defense / Commander of Police } \\
\text { Number Kep / } 728 \text { / XII / } 1970 \text { dated December 31, } 1970 \\
\text { concerning the List of Assessment for Members of ABRI; } \\
\text { 5. Decree of the Armed Forces Number: Kep / 06 / X / 1991 } \\
\text { dated July 7, } 1997 \text { concerning Improvements to the } \\
\text { Organization and Procedures of the Indonesian Navy; } \\
\text { 6. Decree of the Kasal Number Skep Number } 879 \text { / V / } 2003 \\
\text { dated May 29, 2003 concerning List of Assessment of } \\
\text { Navy Military Personnel; } \\
\text { 7. Kasal Decree Number: Skep / 1021 / III / 1987 Regarding } \\
\text { the Pattern of Personnel Development (PUM-102) } \\
\text { 8. Decree of the Armed Forces Number: Kep / 08 / VII / } \\
\text { 1997 dated July 7, } 1997 \text { concerning the Improvement of } \\
\text { Principal Organizations of the Indonesian Navy's } \\
\text { Procedures; } \\
\text { 9NI Commander Regulation No. } 53 \text { of } 2017 \text { Regarding the } \\
\text { Use of TNI Personnel; } \\
\text { 10. Circular number: SE / 25 / XII 2018 concerning the } \\
\text { Implementation of the New MDP Transition Period for } \\
\text { TNI Navy Officers Based on TNI Commander Regulation } \\
\text { Number 40 Year 2018 Concerning the Second } \\
\text { Amendment to TNI Commander Regulation Number 50 of } \\
\text { 2015 Concerning the Departure of TNI Soldiers. }\end{array}$ & $\begin{array}{l}\text { The } \\
\text { suitability } \\
\text { of } \\
\text { program } \\
\text { planning } \\
\text { in the } \\
\text { Organizati } \\
\text { on of the } \\
\text { Indonesian } \\
\text { Navy in } \\
\text { Jakarta } \\
\text { with } \\
\text { existing } \\
\text { policies }\end{array}$ \\
\hline & & $\begin{array}{l}\text { II. I. Program Objectives } \\
\text { Based on Technical Instructions Number: juknik / } 01 \text { / VI / } 2003 \text { / } \\
\text { Dismin Year } 2003 \text { Regarding Procedures for Filling in the List of } \\
\text { Military Navy Personnel Assessment (Dapenpersmil TNI AL) } \\
\text { 1. 1Brought about a systematic and regular assessment of the } \\
\text { Condition of Personnel which is the implementation of the }\end{array}$ & $\begin{array}{l}\text { Achievem } \\
\text { ent of } \\
\text { objectives } \\
\text { in the } \\
\text { Indonesian } \\
\text { Navy }\end{array}$ \\
\hline
\end{tabular}




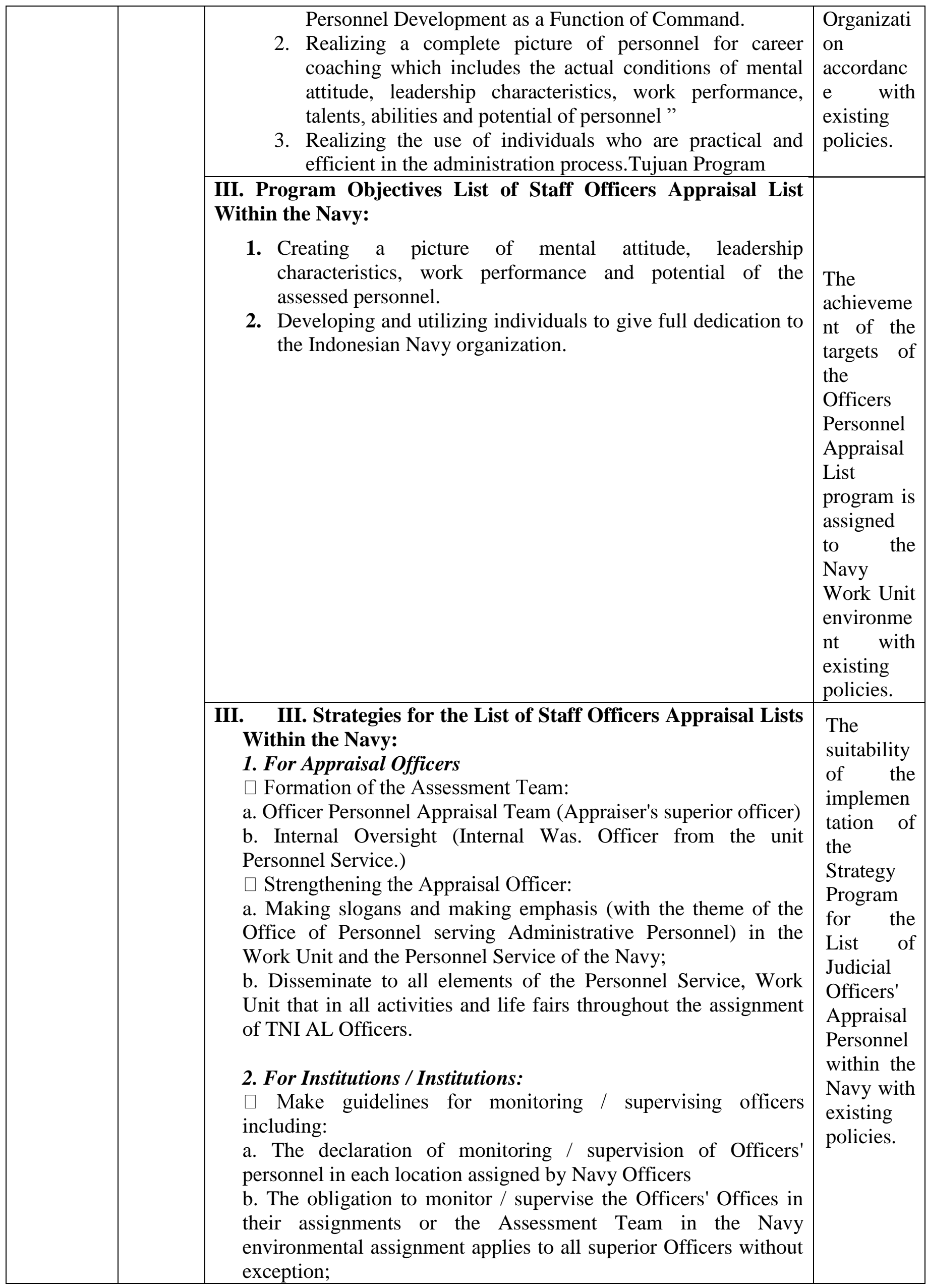




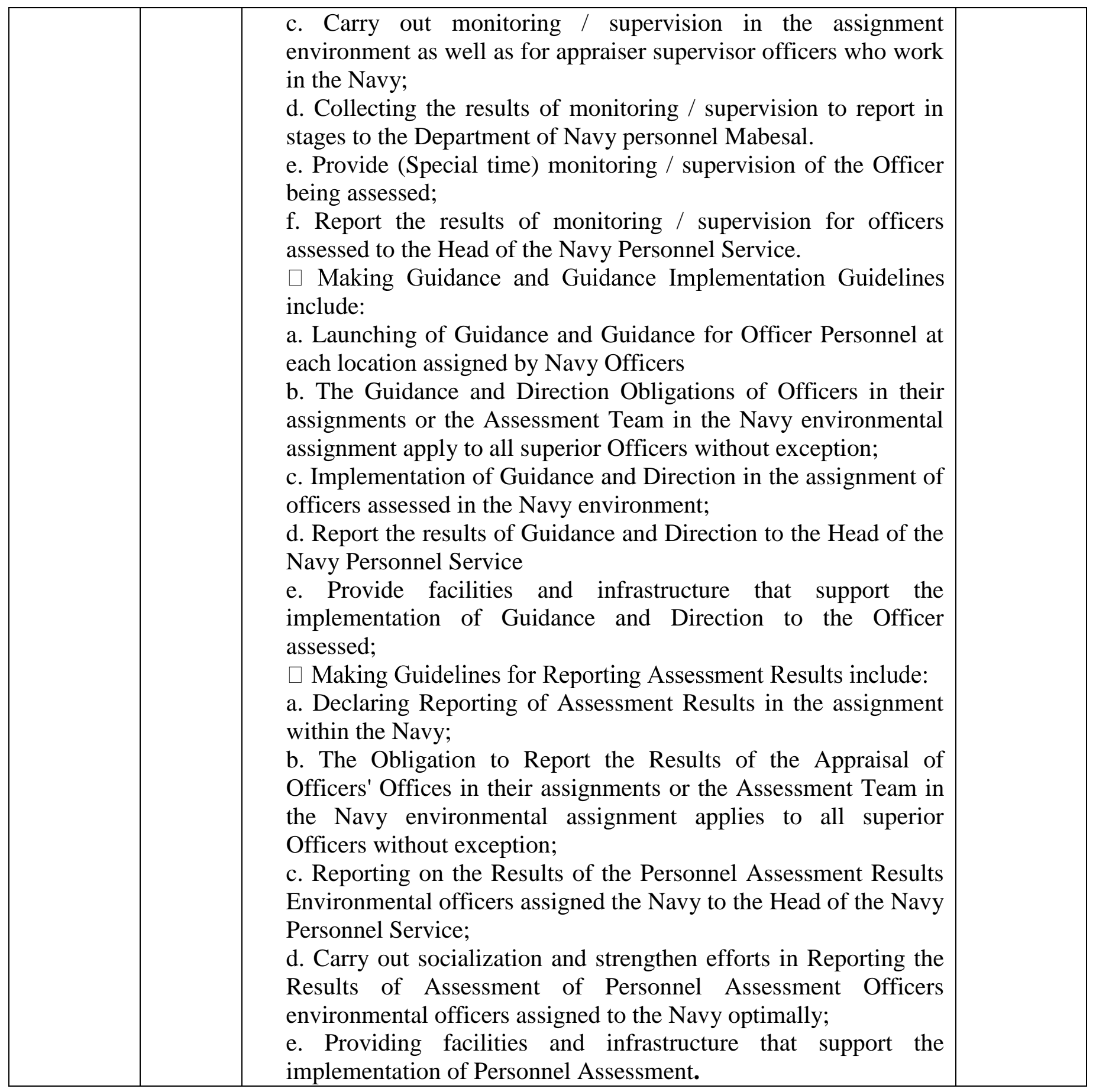

\section{Grids of the Success Criteria of Installation Evaluation}

Table 3: Criteria / Success of the Installation Evaluation

\begin{tabular}{|l|l|l|l|}
\hline $\begin{array}{l}\text { Evaluati } \\
\text { on } \\
\text { Stages }\end{array}$ & Sub focus & Evaluated Aspects & $\begin{array}{l}\text { The Success } \\
\text { Criteria }\end{array}$ \\
\hline $\begin{array}{l}\text { Network } \\
\text { ing } \\
\text { Installat }\end{array}$ & $\begin{array}{l}\text { Correlation } \\
\text { of program } \\
\text { implementat }\end{array}$ & $\begin{array}{l}\text { I. Cooperation in program activities } \\
\text { 1. Cooperation between the Personnel Service in } \\
\text { the unit and the Navy Personnel Service; } \\
\text { Collaboration between the Navy Personnel } \\
\text { Service with other relevant agencies:: TNI } \\
\text { Headquarters; Indonesian Army, Indonesian Air } \\
\text { Force; Indonesian Ministry of Defense; Private }\end{array}$ & $\begin{array}{l}\text { The suitability of } \\
\text { collaboration } \\
\text { activities with the } \\
\text { requirements of the } \\
\text { conditions in the } \\
\text { Assignment }\end{array}$ \\
\hline \hline
\end{tabular}




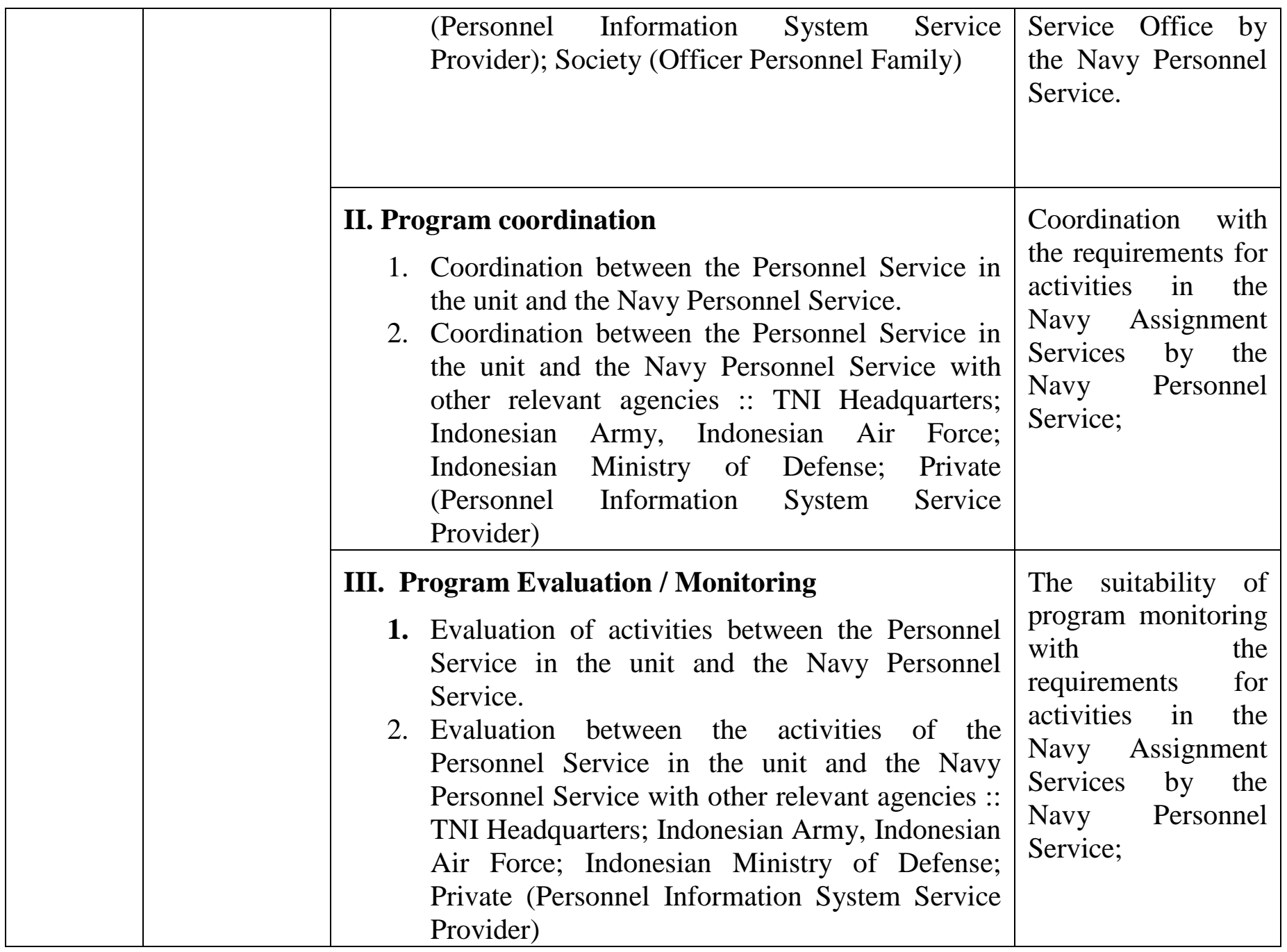

\section{Grids of the Success Criteria of Process Evaluation}

Table 4: The Success Criteria of Process Evaluation

\begin{tabular}{|c|c|c|c|}
\hline $\begin{array}{l}\text { Evaluation } \\
\text { Stages }\end{array}$ & Sub focus & Evaluated Aspects & The Success Criteria \\
\hline $\begin{array}{l}\text { Implementati } \\
\text { on Process }\end{array}$ & $\begin{array}{l}\text { Program } \\
\text { Implementat } \\
\text { ion }\end{array}$ & $\begin{array}{l}\text { Program description: } \\
\text { 1. Fill in the program } \\
\text { 2. Standard Operating Procedures: Core } \\
\text { program settings; } \\
\text { 3. HR Management; Work process; } \\
\text { Supporting program; } \\
\text { 4. Procurement of supporting facilities / } \\
\text { facilities; Activity budget } \\
\text { 5. Monitoring \& Evaluation Program } \\
\text { (MONEV) \& }\end{array}$ & $\begin{array}{l}\text { Appropriateness of } \\
\text { the implementation of } \\
\text { the Officers' Officer } \\
\text { Valuation List within } \\
\text { the Navy with the } \\
\text { implementation } \\
\text { instructions in the } \\
\text { existing regulations }\end{array}$ \\
\hline
\end{tabular}

\section{Grids of the Success Criteria of Product Evaluation}

Table 5: The Success Criteria of Product Evaluation 


\begin{tabular}{|c|c|c|c|}
\hline $\begin{array}{l}\text { Tahap } \\
\text { an } \\
\text { Evalua } \\
\text { si }\end{array}$ & Sub focus & Evaluated Aspects & The Success Criteria \\
\hline $\begin{array}{l}\text { Produc } \\
\mathrm{t}\end{array}$ & $\begin{array}{l}\text { Results of } \\
\text { program } \\
\text { implementat } \\
\text { ion }\end{array}$ & $\begin{array}{l}\text { 1. Implementation of activities in } \\
\text { measuring the quantity of } \\
\text { performance measures of officers } \\
\text { of the Indonesian Navy; } \\
\text { 2. Implementation of activities in } \\
\text { changing the quantity of work } \\
\text { unit performance; } \\
\text { 3. Implementation of activities in } \\
\text { changing the performance of } \\
\text { technical implementers assessing } \\
\text { Officer Personnel in the } \\
\text { Environmental Assignment of } \\
\text { the Indonesian Navy } \\
\text { 4. Implement improvements in } \\
\text { program support facilities }\end{array}$ & $\begin{array}{l}\text { - Appropriateness of the implementation } \\
\text { of activities with an increase in the } \\
\text { Performance of Officers in the } \\
\text { assignment within the Navy; } \\
\text { - Suitability of the implementation of } \\
\text { activities with changes in the quantity of } \\
\text { work unit performance } \\
\text {-The appropriateness of the } \\
\text { implementation of the activities with } \\
\text { changes in the performance of the } \\
\text { technical implementers assessing Officer } \\
\text { Officers in the Environmental } \\
\text { Assignment of the Navy } \\
\text {-The appropriateness of the } \\
\text { implementation of activities with the } \\
\text { improvement of program support } \\
\text { facilities in the Navy's Environmental } \\
\text { Assignmen }\end{array}$ \\
\hline
\end{tabular}

\section{Grids of the Success Criteria of Benefit Evaluation}

Table 6: The Success Criteria of Benefit Evaluation

\begin{tabular}{|l|l|l|l|}
\hline $\begin{array}{l}\text { Evaluati } \\
\text { on } \\
\text { Stages }\end{array}$ & Sub focus & $\begin{array}{l}\text { Evaluated } \\
\text { Aspects }\end{array}$ & The Success Criteria \\
\hline Benefit & $\begin{array}{l}\text { Benefits } \\
\text { of the } \\
\text { program }\end{array}$ & $\begin{array}{l}\text { Implementatio } \\
\text { n of the entire } \\
\text { Appraisal List } \\
\text { for Officers } \\
\text { Personnel } \\
\text { assigned to the } \\
\text { Indonesian } \\
\text { Navy. (Dapen } \\
\text { Persmil TNI } \\
\text { AL) }\end{array}$ & $\begin{array}{l}\text { There has been an increase in awareness of the importance of } \\
\text { the Navy officers' assessment activity program. With reference } \\
\text { the behavior problems of officers in the assignment within the } \\
\text { Navy, through the Improvement Behavior program by setting } \\
\text { Standard Operating Procedures ( SOP), and Monitoring and } \\
\text { Evaluation (MONEV) based on Information and } \\
\text { Communication Technologies (ICT) in the form of a Dash } \\
\text { Board about Officer Data in a comprehensive manner after the } \\
\text { Navy AL Officer Officer assessment program is implemented, } \\
\text { which is only related to performance evaluation / evaluation. }\end{array}$ \\
\hline
\end{tabular}

\section{Grids of the Success Criteria of Behavior}

Table 7: The Success Criteria of Behavior

\begin{tabular}{|l|l|l|l|}
\hline $\begin{array}{l}\text { Evaluati } \\
\text { on } \\
\text { Stages }\end{array}$ & $\begin{array}{l}\text { Sub } \\
\text { focus }\end{array}$ & Evaluated Aspects & The Success Criteria \\
\hline
\end{tabular}




\begin{tabular}{|c|c|c|c|}
\hline $\begin{array}{l}\text { Behavio } \\
\mathbf{r}\end{array}$ & $\begin{array}{l}\text { Behavio } \\
\mathbf{r} \text { of } \\
\text { Navy } \\
\text { Officers }\end{array}$ & $\begin{array}{l}\text { Behavior of Navy Officers } \\
\text { after implementation of the } \\
\text { entire Program for the } \\
\text { Assessment of Personnel } \\
\text { Officers serving in the } \\
\text { Indonesian Navy } \\
\text { environment. (The Program } \\
\text { of Dapen Persmil TNI AL) }\end{array}$ & $\begin{array}{l}\text { There has been an increase in awareness of the } \\
\text { importance of the Navy Navy officers' assessment } \\
\text { activities program by referring to the behavior of } \\
\text { officers in the assignment within the Navy, } \\
\text { including: Moral Attitudes; Dedication Attitude; } \\
\text { Discipline Attitude; Loyalty Attitude; Honesty } \\
\text { Attitude; Military Attitude; Leadership } \\
\text { Responsibility Attitude }\end{array}$ \\
\hline
\end{tabular}

7. Criteria / Success Results Stages (Results)

Table 9: Criteria / Success Stages of Results Stages (Results)

\begin{tabular}{|c|c|c|c|}
\hline $\begin{array}{l}\text { Evaluati } \\
\text { on } \\
\text { Stages }\end{array}$ & $\begin{array}{l}\text { Sub } \\
\text { focus }\end{array}$ & $\begin{array}{l}\text { Evaluated } \\
\text { Aspects }\end{array}$ & Criteria / Success \\
\hline Results & $\begin{array}{l}\text { Results } \\
\text { of the } \\
\text { overall } \\
\text { impleme } \\
\text { ntation } \\
\text { of the } \\
\text { Progra } \\
\text { m of } \\
\text { Dapen } \\
\text { Persmil } \\
\text { TNI AL } \\
\text { in the } \\
\text { form of } \\
\text { Officer } \\
\text { Behavio } \\
r \text { in the } \\
\text { work } \\
\text { union. }\end{array}$ & $\begin{array}{l}\text { Decline in } \\
\text { the } \\
\text { Violation of } \\
\text { Indonesian } \\
\text { Navy } \\
\text { Officers in } \\
\text { the work } \\
\text { union }\end{array}$ & $\begin{array}{l}\text { - There has been an increase in awareness of the importance of the } \\
\text { Navy officers' assessment activity program. With reference to the } \\
\text { Zero-Based Behavior Abuse Program (ZEBAP), namely achieving a } \\
\text { reduction in the number of zero-based violations of TNI AL } \\
\text { Officers related to behavior problems (behavior) by: Implementing } \\
\text { the Human Resources Information System (HRIS),; Establish } \\
\text { Operating Procedures (SOP) DAPEN PERMIL TNI AL; Carry out } \\
\text { Monitoring and Evaluation (MONEV) based on Information and } \\
\text { Communication Technologies (ICT), namely Dash Board., Navy } \\
\text { Personnel Officers.; Continuous Behavior Improvement Program } \\
\text { (CBIP). } \\
\text { - Indonesian Navy Officers' Dash Board Personnel includes } \\
\text { comprehensive Officer Data after The Program of Dapen Persmil } \\
\text { TNI AL includes: Moral Attitudes; Dedication Attitude; Discipline } \\
\text { Attitude; Loyalty Attitude; Honesty Attitude; Military Attitude; } \\
\text { Leadership Responsibility Attitude }\end{array}$ \\
\hline
\end{tabular}

Referring to the various descriptions above, the researchers chose to use the Provus Discrepancy Evaluation Model, the Provus Discrepancy Evaluation Model (DEM), and Kirkpatrick Evaluation Models Level 3 \& Level 4 ((Philips, Jack.J \& Ron Drewstone, 2000: 122). Philips, Jack.J \& Ron Drewstone, 2000) stated that the data were obtained through observation instruments, interviews, documentation and using descriptive survey research methods, by means of explanotary and qualitative approaches. Therefore, researchers' understanding of the stages that became sub- focus is able to reveal comprehensive information from the implementation of the Navy Dapen Program.

Then, the focus of this research is the level of conformity between the standards (standards) that have been determined in the program with the actual performance (performance) of the program (Widiyoko, 2013: 187-189). Thus, the document analysis technique in this study is in accordance with the evaluation standards as stated by (Karasar, 2012) in (Ulum, 2015: 106) that evaluation standards include criteria to guide researchers as evaluators, analyze existing records, and the document analysis of the reliability and validity of the evaluation is illustrated by researchers to state the evaluation standard as a utility standard around the topic of document evaluation to present the resources investigated as well as data obtained information that is supported to the authorities (Karasar, 2012) in (Ulum, 2015: 106) . Furthermore, in order to dig deeper into the analysis of the policies of the program of Dapen Persmil TNI AL, the evaluation standards used can be described as follows: 


\section{Evaluate the Standard Design Criteria}

Based on the variant of the answers obtained from the informant, a description is obtained that explains the evaluation context in the design aspects. The researcher is of the opinion that in relation to the legal basis that has been used, the Indonesian Navy Personnel Service No. 43 / X / 2018 Regarding the Use of the Navy Personnel Assessment List issued by the Navy Personnel Service is still adequate. In the field findings also revealed the fact that the Navy Personnel Service issued another Circular which also supported the implementation of, the program of Dapen Persmil TNI AL namely through Technical Guidelines / 01 / VI / 2003 concerning Procedures for Filling in the List of Navy Personnel Military Appraisal (Dapen Persmil TNI AL) to follow the progressive steps referred to with respect to efforts to implement the assessment within the Navy.

The findings of researchers in the field, namely the views of other informants who continue to strive to increase the degree of legality hierarchy of Juknik / 01 / VI / 2003 concerning Procedures for Filling in the Appraisal List of the Navy Military Personnel (Dapen Persmil TNI AL) issued by the Navy Personnel Service. In this case, for the basic legal hierarchy of Juknik / 01 / VI / 2003 concerning Procedures for Filling in the List of Ratings of the Navy's Military Personnel (Dapen Persmil TNI AL), it can be raised / upgraded to a Regulation of the TNI Commander, which until now still uses the old regulations namely ABRI and published in 1970. Based on the existing Circular, the researcher is of the opinion that after seeing the existing situation and conditions related to the implementation of the program of Dapen Persmil TNI $\mathrm{AL}$, the increase in the legal basis hierarchy actually does not significantly influence the achievement of the program's objectives. This is based on situations and conditions on the ground that reflect aspects of legality or the level of the regulatory hierarchy that constitutes the legal umbrella for the program of Dapen Persmil TNI AL. The informants are of the opinion that they are more inclined to look at other elements, such as facilities and infrastructure as well as human resources.

The opinion of the informant was similar to (Supandi, 2015: 21), which said that the main strength of all the Navy's strength development programs was located in the quality of human resources (HR) so that they sought to improve the education and professional training of the sea departures periodically and sustainably in harmony with technology Alutsista, science and technology development and organizational needs. Researchers 'findings are related to the number of personnel managing officers' violations in the Navy Personnel Service that is not proportional to the number of reports / data received. both qualitatively and quantitatively. This has an impact on the implementation of the program of Dapen Persmil TNI AL which cannot be carried out properly. For example: the assessment system that is implemented is still very simple, the knowledge and skills of the Supervisor / Appraiser need to be improved with a human resource management (HRM) approach because of the improvement in the quality of human resources in the Indonesian Navy is a fact that must be present and carried out in a plan, intensive, focused and affective, and an efficient development process.

This opinion is supported by (Schuler \& Jackson, 1987; Danny et al., 2008) in (Gill, \& Meyer, 2011: 5) which states the suitability between human resource management (HRM) and business strategies to improve effectiveness and capability and capacity The organization achieves its goals by utilizing available resources (Mwaniki \& Gathenya, 2015: 433). This makes it logical to look at the work experience of each informant in his daily life dealing directly with the Officer in question.

The informants positioned the legal basis available only as a reference for regulations that must be carried out within the Navy, as a norm governing the actions that may be carried out or the actions that should not be done. If the rule is violated, there are consequences that must be faced in the form of sanctions that are also contained in the rule. Other factors which according to the researcher are more significant to support the achievement of the objectives of the program of Dapen Persmil TNI AL are obey of the law or obligation to obey the law (Sevel, 2018: 37).

Based on the researcher's findings from the information submitted by the informant, it can be seen that if evaluated from the design aspect, the rules should be made in accordance with the objectives of the program. However, the findings of the researchers regarding this, are the lack of socialization of the objectives, targets and strategies of the Navy Navy Dapen Program to the Appraisers/Superiors/ Officers and Assessed/Subordinate Officers so as to cause the strategies implemented to be ineffective. The indicator is 
that there are still many officers who are assessed / subordinates who do not have the awareness and obedience to the rules that have been made so that it is necessary to increase the socialization of regulations or laws which are certainly very beneficial for Navy Officers because the regulations must be made according to need (Rosana, $2014: 24$ ). This has always led to cracks for superiors / appraisers to provide opportunities for officers / appraisers who are not aware of their obligations while serving in the Navy environment.

\section{Correlation Evaluation of Program Implementation}

The findings of the researcher are related to the correlation between the implementation of the program of Dapen Persmil TNI AL that there are two views originating from the informants' answers as follows: first, stating that the implementation of the network of cooperation with agencies outside the Navy, such as Spers Headquarters of the TNI has been running effectively in accordance with Dapen's objectives Indonesian Navy Armed Forces The Navy Personnel Service, can not work alone, in seeking the implementation of the program of Dapen Persmil TNI AL. The Navy Personnel Service needs real support from outside parties as does the TNI Headquarters Spers.

Effective cooperation is seen and measured from the implementation of joint meetings and coordination, conducted by the Spers of the TNI to make rules for the Assessment of TNI Personnel, namely with the Army and Air Force. An agreement has been formed or the readiness to cooperate in carrying out the assessment of Officers in each Force has runs well. The implementation of other cooperation networks can also be seen from the cooperation as one of the conditions needed for the implementation of the vision and mission, in order to improve organizational performance (du Plessis, Douangphichit, \& Dodd, 2016: 12; Gerry Dessler in Widodo, 2015: 2), and at the same time can improve overall organizational competitiveness through recruitment, training and development, professional development, compensation and benefits, performance appraisal (Ahammad, 2017: 415; Dressler, 2007 in Okoye \& Ezejiofor, 2013: 253), and ensuring compliance law (Benedek, 2012: 136; Dirk Huds, 2010 in Okoye \& Ezejiofor, 2013: 253 - 254).

In this case, the collaboration between the Navy Personnel Service and Personnel Service Offices in all Indonesian assignments. Regarding the training and technical development required by the Appraisers / Superiors is in the form of knowledge and skills (Collin, Van der Heijden, \& Lewis, 2012: 155, Susan, 2012 in Okoye \& Ezejiofor, 2013: 251) to utilize technology and the environment (Saha, Chatterjee, Gregar, \& Sáha, 2015: 64), enrichment and improve employee competence (Collin, Van der Heijden, \& Lewis, 2012: 157) to be able to adapt to changing needs of the times (Jagannathana, Rab and Maclean, 2019: 4), changing attitudes and influencing behavior to be important and strategic in organizational development (Rafiei, \& Davari, 2015: 36), based on observations as well as answers obtained from informants that there are several informants' views related to the existence and effectiveness of the Appraisal / Supervisor Officer who is in charge of the Navy. Appraisal of officers by appraisers / superiors is considered a futile effort because officers who carry out appraisal of the program of Dapen Persmil TNI AL are not maximized, that is, they have not used an information and communication technology based assessment system, there are limited numbers of units and human resources (HR) technology managers.

An interesting finding is related to the cooperation that has been carried out by the Personnel Service Unit with the Navy Personnel Service Office, namely the negative excess felt unilaterally from the Service Unit party which only provides administrative records. For example, when a violation is committed by an Indonesian Navy Officer in an assignment, it is not immediately used as a record and report, and what appears to the public level is a claim about the failure of the Service Personnel Service and the negative excess is placed on the Appraisal Officer / supervisor where the incident take place. Another problem that becomes a separate challenge is when there are other agencies such as the Personnel Unit not providing data and information related to moral issues involving Navy Officers due to concerns from the Personnel Service Unit the occurrence of "leakage" of information so that the data and information is only allowed for the Personnel Service Unit alone.

In this context, researchers understand the arguments built in a collaboration should be evaluated (Nugroho, 2009: 135) in order to provide mutual benefits to each party (mutual benefit). The argument was built using a moral and ethical approach. This understanding is useful to ensure the sustainability of cooperation in a long time (sustainable corporation) in realizing shared goals between the parties. Evaluation is needed to see 
the gap between expectations and reality because the evaluation or monitoring of the program of Dapen Persmil TNI AL is related to the validity of the Circular Letter, Juknik / 01 / VI / 2003 concerning Procedures for Filling in the Navy Military Personnel Assessment List (the program of Dapen Persmil TNI AL) 2018 should have been evaluated and monitored. This becomes very important and strategic because the implementation of the program of Dapen Persmil TNI AL should not only assess it from the budget aspect, but also be evaluated and evaluated from the aspect of its implementation, which is related to correlation or cooperation with other agencies.

\section{Evaluate the Implementation of Program Management}

Judging from the implementation of the program there are several aspects of concern to researchers as follows: first, from the aspect of implementation and the realization of the contents of the Standard Operating Procedure (SOP), from the findings it can be seen that the Appraisal Officer / supervisor has carried out in accordance with the specified SOP, namely the SOP The assessment of Officer Personnel originating from Government Laws and Regulations due to the unavailability of SOPs specifically to support the Navy AL Dapen program so that the practice of Total Quality Management (TQM) is ignored in the implementation of the program of Dapen Persmil TNI. If, TQM is adopted in the Dapen Persmil TNI AL program, then cases of alleged moral violations will be inspected by officers who are suspected of being involved in violations, then internal sanctions will be given according to the applicable rules based on measured SOPs, imposing sanctions in the form of postponement of rank until dismissed with no dismissal respect.

Understanding TQM in an organizational context means that all work in an organization is building quality into every step of the work process, changing the quality of the environment for the better, reducing the impact of mismanagement, responsible for organizational transformation from mediocrity to the best (Houston, 2004 : 1), sets high standards for measuring the effectiveness and efficiency of quality improvement models (Rudes, Viglione, \& Porter, 2004). According to experts in (Rudes, Viglione, \& Porter, 2004) that Total Quality Management (TQM) / Continuous Quality Improvement (CQI) works best in process-oriented organizations that are customer-focused and where management uses additional methods for improvement (Kennerfalk \& Kelfsjo, 1995) using tools to manage and control the product development process (Kennerfalk \& Kelfsjo, 1995) including policy dissemination, management processes, and performance evaluation (Kennerfalk \& Kelfsjo, 1995).

Based on the description of the TQM, it can be interpreted that TQM is a guarantee of the quality of the product or program produced and ensures the manufacturing process of the product or program is in accordance with the specified standards and requirements (Ali \& Khatoon, 2016: 115). This opinion is related to the context of the implementation of Dapen Persmil TNI AL that TQM has actually been carried out, namely in the form of inherent supervision (Waskat) as Telegram Kasal No 005 / ITJ / 0912 (https://koarmada1.tnial.mil.id/ PENPAS / tabid / tabid / 66 / articleType / ArticleView / articleId / 52 / IMPROVE SUPERVISION OF MELELES -DI-KOARMABAR.aspx Accessed March 19, 2020) that the success of inherent supervision (Waskat) within the Indonesian Navy as a guide: Men Regulation Kasal No Perkasal / 58 / VII / 2009 , Implementation manual (Bujuklak) inherent supervision (Waskat) can certainly be seen from several indicators as follows: (1) The creation of regularity, openness and smooth implementation of duties., (2) Increased compliance with the provisions of the applicable laws and regulations, and 3) Decreased volume of disciplinary violations, desertion, violations of law or criminal offenses and reports of public support. Kasel Telegraph No. 005 / ITJ / 0912 is a form of Waskat, i an integral access to actions and activities carried out continuously by officers as leaders and all soldiers and employees within the Navy to provide adequate confidence in the achievement of organizational goals through effective and efficient activities, reliability of reporting, and adherence to laws and regulations .

Seeing the importance of the role of the Waskat in order to achieve the goals and objectives of the organization and to realize good organizational governance, officers as leaders within the Navy must be able to make the application of the Waskat a joint responsibility not only in the smallest work units but up to each individual. In this case, the implementation of Waskat was felt to depend very much on the commitment, role models of officers as leaders within the Navy and the good intentions of all elements of the Navy Assignment to be carried out in the context of supporting the achievement of the objectives of the program 
of Dapen Persmil TNI AL. This has become an important part of achieving the objectives of the program of Dapen Persmil TNI AL to be carried out because of the enactment of the Technical Guidelines / 01 / VI / 2003 regarding Procedures for Filling in the TNI Navy Personnel Appraisal List not yet fulfilling modern and professional organizational management criteria.

The success of the system or mechanism can actually be an indicator of the success of the program of Dapen Persmil TNI AL . In the current understanding of researchers, the key word is to increase the integrity of the appraisal officers / supervisors and / or officers of the Navy Assignment from the highest level to the lowest level and the environment around the assignment unit. Responsible management Appraisal Personnel should intensively build a shared commitment to internalize the values in the program of Dapen Persmil TNI AL as an effort to realize the achievement of its objectives, namely organizational culture has excellence, allows staff to create new programs and procedures through Total Quality Management (Houston (2004: 1)

\section{Evaluation of the Implementation of Program (Results)}

Associated with aspects of the results of the implementation of the program of Dapen Persmil TNI AL, researchers found that the variant of the answers varied from informants. This is interesting because the answer is influenced by the capacity of the informant's position in the context of the implementation of the program of Dapen Persmil TNI AL, and internally it is stated that the achievement has reached $90 \%$ quantitatively. But from the point of view of the external party the superior officer / stated that the program of Dapen Persmil TNI AL was not successful. In this case, the researcher can understand the different variants of answers from the informant and from the external superior / Appraisal Officer related to the implementation of the program of Dapen Persmil TNI AL. In the opinion of the researcher, the reality condition reflected in the field is the ideal claim of the success of the program that can only be said to be successful if the officers' violations in morality are clean up to $100 \%$ in terms of assignments within the Navy assignments. This researcher's view is reinforced by claims from internal parties that objectively the program of Dapen Persmil TNI AL has not been 100\% successful. On the other hand, empirically based on the findings of researchers it cannot be denied that the program has been realized even though the achievement is not $100 \%$. Then, based on the views of external parties, it was stated that the program had not been successful because of the fact that there were still many moral violations.

In this regard, the researcher is of the opinion that in carrying out organizational tasks it still tends to occur is the process of "exchanging" interests between the superior / appraisal officer with the officer who is valued and or the Navy Officer. Therefore, it is an impossibility of achieving the objectives of the the program of Dapen Persmil TNI AL with very inadequate facilities and infrastructure where the assessment only uses notes in the form of penilan sheets and is not based on Information \& Communication Technology (ICT). This view is in line with (Václav, Antonín, \& Petra, 2011: 59) which states that a modern approach to HR management including in this case the implementation of the program of Dapen Persmil TNI AL must take into account additional perspectives with the use of Information \& Communication Technology (ICT), which is a system human resource information (Silva \& Lima, 2018; 115) using special actors and tools ( ̌̌epa, 2007 in Václav, Antonín, \& Petra, 2011: 59-61) to evaluate employee efficiency, build tools and guidelines for management review, designing administrative and support processes, placement and dismissal (Václav, Antonín, \& Petra, 2011: 59-61).

According to (Faseeh ullah khan, 2013: 68), performance appraisal can be interpreted as structured formal interaction between subordinates and supervisors, which is usually in the form of periodic interviews (annual or semi-annual), where subordinate's work performance is examined and discussed, with the aim of identifying weaknesses and strengths and opportunities for skills improvement and development and assessment results are used to identify performers who lack performance according to standards which may require some form of counseling, or in extreme cases, dismissal of demotion or reduction in wages. In this context, the problem is, namely the ratio of appraisal officers / superiors to the number of officers assessed so that it results in ineffectiveness in carrying out the supervisory function. Based on needs, the number of appraisers / superiors with the number of officers to be monitored is estimated to be ideally 1 person / appraisers / superiors assess 10 officers assessed. However, researchers' findings that the superior officers / appraisers tend to tolerate the situation and conditions of existing limitations. 
This has implications for the implementation of the program of Dapen Persmil TNI AL related to the assessment, supervision, guidance and completion of officers' reporting in the Navy environment. Current conditions so far the Appraisal Officer in charge mainly evaluates routines in the form of apples and directions from the Chairman. Then, it is necessary to increase integrity, for example through a program of continuous behavior improvement (CBIP), which is to instill the values of integrity in order to change the mindset of the appraisers / superiors and / or officers in carrying out their duties. In the end, the researchers concluded that based on the number of officers violating from 2016 to 2018, it was indicated that the supervision and recording officers were still weak in the Navy assignment.

\section{Evaluate the Benefits of Program}

From the aspect of the beneficiaries of the the program of Dapen Persmil TNI AL, it can be seen from two parties, first, the Appraiser / officer / officer / officer as the organizer of th eprogram; and second, from the point of view of Officers being rated as subjects of assessment and subordinates / members of where Officers are assessed. Internal parties claimed that the benefits of the program of Dapen Persmil TNI AL were obtained in the form of discipline and order in daily life within the Navy's assignment environment. From the findings of researchers in the field, the informant conveyed verbally that by suppressing discipline in the assignment environment had an impact on decreasing violations within the Navy assignments, given that most violations within the Navy were still caused by irregular disciplinary officers. However, regarding this matter, the researcher did not obtain valid data in the form of numbers or percentages that referred to the decreasing violations. External parties have more or less the same view, if the program is successful then the officers' rights are fulfilled. Related to this is the researcher obtained from the variant of answers in the field which states that the program of Dapen Persmil TNI AL is very beneficial for all parties. However, there is a weak point in the implementation of the Officer's Discipline, meaning that the Act of Disciplinary Violations by Officers has an impact on the number of violations within the assignment environment.

Based on the observations of researchers, of the 3 (three) institutions in the Assessment System (Navy Military Police, Judicial Supervisors, and Military Courts) tend not to cooperate with the personnel assessment institution even though the three institutions are assumed to be suppliers which significantly influence the decrease in officers' disciplinary violations. On the other hand, the Navy Personnel Service, which is the Personnel Service of the Navy, tends not to be able to do much with the real conditions in which in terms of technology system infrastructure alone is very limited and inversely proportional to the incoming data supply, so it seems as if causing an absence of effective filters in the rating system. Therefore, researchers argue that it is time to make corrections from the Navy Navy Dapen program because violations in the work environment occur not only because of increased discipline violations but the behavior / attitudes of employees and influence on performance.

\section{Behavioral Evaluation}

Judging from the aspect of recipient behavior from the program of Dapen Persmil TNI AL, it can be seen from two parties, first, the officer / officer / employee / superior officer as the organizer of the assessment; and second, in terms of the officers assessed. From the internal side stated that the benefits of the program btained in the form of morale and honesty as soldiers / officers in daily life in the service environment of the Navy. From the findings of the researchers in the field, the informant conveyed verbally that by suppressing the behavior of moral violations and honesty in the assignment had an impact on decreasing violations in the Navy's work environment. Considering that the majority of moral violations in the Indonesian Navy were not yet a concern in the assessment by the Supervisor / Appraiser Officer who was in the assignment. In this case, the researcher did not get valid data in the form of numbers or percentages that showed a decrease in violations of morality and honesty. From the point of view of officers judged as a result of the attitude of the program of Dapen Persmil TNI AL is that they have fulfilled their rights as TNI Navy officers as they should, particularly in relation to behavioral violations associated with the preconditions for obtaining the rights of TNI AL officers from the right to obtain facilities, the right to receive coaching for promotion, education and assignment of officers.

These efforts are very important to be carried out to analyze the policies of the program of Dapen Persmil TNI AL. Persons because what is currently done is the implementation of the program only from the aspect 
of evaluation, the performance of Officers. Therefore, an information and communication technology-based monitoring and evaluation (MONEV) program approach in the form of a Dash Board, establishes standard operating procedures and implements a program of behavior improvement in a sustainable manner.ICTbased Monitoring \& Evaluation (MONEV) in the form of a Dash Board, setting operational standard procedures and implementing a behavior improvement program on an ongoing basis is expected to change the officers' attitudes effectively or their success can reduce attitudes and behavior violations (Ramadhan, 2016: 2). According to Aspers Kasal (2016: 16-17) quoted from the report on violations of TNI Navy officers, in a career control session of TNI AL personnel, Jakarta: Staff Personnel Mabesal, 2016 stated that the increase in Officer Violations in the period of 2016-2018 was as follows:

1. In 2016 (the number of violations 115, the highest moral violations of personnel in dishonesty by doing business in a number of 70 personnel there were 50 officers, misuse of authority 16 personnel were officers, immoral number 16 personnel there were 12 officers and there were 5 officers narcotics). Whereas in 2017 (Number of Violations 551, moral violations of the highest personnel in the abuse of the authority of 409 Officer officers, dishonesty by doing business totaling 57 Personnel there were 40 Personnel Officers, 40 officers were misused, 66 Personnel were officers, immoral number 66 Officer 50 and Mangkir 7 there are 5 Officers), and in 2018 total violations tend to be recorded down, namely 238 various types of cases. An increase in moral cases that continues to increase (see graphic 4.1) triggers an officer moral crisis and eventually leads to a leadership crisis within the Navy. This happened in 2017, there was a problem with the Officers group whose purpose was contrary to the guidelines and attitudes of the Navy Officers or who are often referred to as the North Armada group;

2. The majority of the provisions for moral violations New officers are threatened with imprisonment and inefficient administration for spending too much on the budget. Imprisonment, administration until being dismissed from service also has not been able to recover the losses suffered by the Navy in forming an Officer;

3. Providing alternative thoughts related to the analysis of officers' attitudes / morals in the punish policy. Moral policies or laws are always associated with prohibited acts and punishments that are threatened.

Graph 1 :: Recapitulation of Number of Violations in Various Cases by Officers after the Implementation of the Program Dapen Persmil TNI AL 


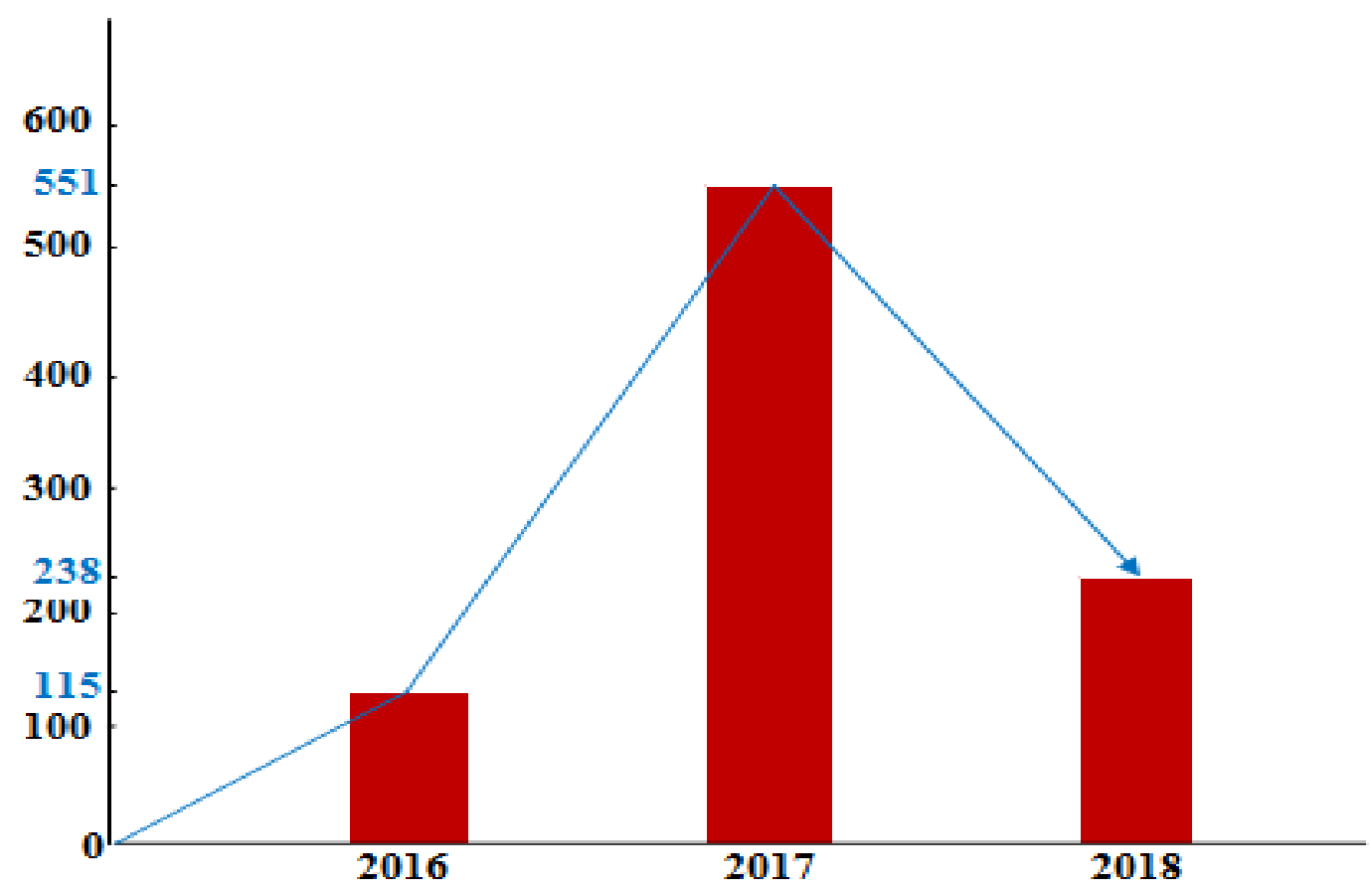

Based on graph .1., The researcher is of the opinion that it is time to harmonize the four rules in the Officers' rating system in order to see their tangent and synergy. Based on the observations of researchers, of the 3 (three) institutions in the Assessment System (Supervisors / Officers / Officers, Unit Personnel Officers, and Personnel Offices of the Navy) tended not to cooperate in conducting the process of monitoring and evaluation of TNI AL officers after the Dapen Persmil TNI program was implemented. Whereas these three institutions are assumed to be suppliers which significantly influence the decrease in the number of moral violations of Navy Officers.

On the other hand, the Navy Personnel Service which is the Office of the National Army of Spers of the Navy seems to be unable to do much with the real conditions that exist where in terms of the assessment infrastructure alone is very limited and inversely proportional to incoming supplies so this seems to cause the absence of effective filters in the Officer's rating system. Therefore, a paradigm needs to be built that assesses Officers as a continuing effort to carry out the assignment as well as the selection of Navy Officers to serve in the future. In this context, the Mabesal Personnel Service institution has no other effort than to accept and collect the results of the assessment. Therefore, researchers argue that it is time to make corrections from the criminal system in Indonesia. This is in line with the findings of previous researchers who stated that the factors causing an increase in officers' moral violations in the assignment occurred not only because the assessment had been carried out but also occurred as a result of the assessment system.

\section{Impact of the Evaluation Program (Results / Outcomes)}

The implementation of the Officer Personnel assessment program, of course, aims to get good results, such as improving the morale of the Officers. Evaluation of results according to Kirkpatrick, D., L. $(2006,134)$ can be defined as an end result that occurs as a result of officers participating in an assessment program. Associated with aspects of the results of the implementation of the the program of Dapen Persmil TNI AL, researchers found variant answers from the informants. The interesting thing is that the answer is influenced by the capacity of the informant's position in the context of the implementation of the Dapen Persmil Perwira program. Internally the Indonesian Navy stated that the achievement of the Dapen Persmil program had reached $90 \%$. While the views of external parties from the TNI Headquarters stated that this program was not successful because of a fourfold increase in cases from 2016 to 2018.

An external view which states that the Officer Personnel assessment list program has not been successful due to the fact that there are still many cases of moral violation of TNI AL Officers. In this regard, the researcher is of the opinion that in carrying out the assessment tasks it still tends to occur is the process of "uncomfortable" interests between the Assessment Officer and the Staff Officer that is valued and / or the Officer who is the danger. In this case, the researcher sees objectively from the two views above there is a background of conditions that are not ideal, namely the condition of increasing moral violations in the 
assignment compared to the record of reported violations. For example, the findings of researchers in the field, specifically related to moral violations are still felt as conveyed by one of the assessed officers who believes that the abuse of authority is still carried out by officers who were assessed while on duty. The existence of the Bias Too Soft and Too Hard bias situation is the background of the occurrence of practice between the Judging Officer and the Judged Officer. This condition is in line with the results of previous studies because of the lack of operational resources in the assessment as a result, the appraisal officers bring their own resources into the assessment activities, and they make programs, maintain their own networks and organizations (Narag \& Jones, 2016: 18).

Then, in terms of the results of changes in program target behavior, it was felt that it also did not have a significant impact due to the function of the Technical Guidelines / 01 / VI / 2003 concerning Procedures for Filling in the program of Dapen Persmil TNI AL, According to researchers, it was only limited to appeals to The superior officer / appraiser has consequently not caused a deterrent effect on the officer who was assessed. The Officer Personnel Appraisal Register Program has so far been felt to have not occurred. The opinion of researchers is strengthened and supported by valid data, the high number of officers violating the Navy Assignment environment since 2016 to date. This is in line with the findings of previous researchers, repressive efforts undertaken by law enforcement officials, in the form of imposing or giving criminal sanctions to Navy Officers, in this case carried out by the Navy Military police, the Navy Law Office, the Office of Personnel Personnel and the Personnel Office of the TNI AL to conduct law enforcement related to officers' moral violations in practice turned out not to be easy because there were many obstacles or obstacles faced, namely the assessment facilities and infrastructure, the quality of the HR of Appraisers (Sudewo, 2017: 13).

In this context, it should be suspected that weak oversight and monitoring by Officers in the Personnel Service Unit to the Navy Personnel Service on the results of the assessment development are carried out by officials, appraisers / superiors. The results of interviews with informants indicate the reluctance of superiors / appraisers who are supposed to supervise and monitoring when confronted with fellow Officers and Officers assessed. This raises opportunities for violations that are not reported and recorded in the Navy's assignment. Seeing these conditions, it becomes a common challenge to increase the integrity of the Appraisal Officers / superiors and in carrying out their duties, especially in monitoring and monitoring to ensure there are no moral violations within the Navy's assignment environment.

Current conditions during the Appraisal by Appraisal Officers / superiors who are tasked primarily in the appraisal process are only routine in the form of completeness of the administrative requirements for education, administrative requirements for assignments and military appointments at the time. Therefore, it is necessary to increase integrity, for example through Implementing the Pattern of Continuous Behavior Improvement Program (CBIP), which is a mindset change program for all appraisers / superiors in carrying out their main duties and functions as they should. The Continuous Behavior Improvement Program (CBIP) is expected to be able to instill the values of integrity that must be imbued by all Navy officers so as to eliminate officers 'reluctance when conducting surveillance and reporting of officers' moral violations within the Navy's official service environment. Until the end of the research period, researchers have difficulty in obtaining evidence of violations in a valid assignment for the occurrence of officers' moral violations. So far the indications of extortion are based on several cases that have arisen such as immorality and abuse of authority from 2016 to 2017 related to the Career Control session and the coordination meeting of the Navy Personnel Officers once every year. However, in relation to the morality case, the assignment in the unit service is still very poor and tends to be unreported.

\section{Conclusion}

The main strength of all the Navy's development programs lies in the quality of human resources (HR) so that it seeks to improve the education and training of the profession of marine departure periodically and sustainably in harmony with the defense equipment technology, the development of science and technology and the needs of the organization. However, efforts to improve the quality of human resources (HR) tend not to be implemented optimally. For example, the situation and conditions in the Indonesian Navy personnel are related to the problem of officers reporting violation reports that have been received a lot but are not well managed. 
The researchers 'findings are related to the number of personnel managing officers' violations in the Navy Personnel Service that is not proportional to the number of reports / data received. both qualitatively and quantitatively. This has implications for the program of Dapen Persmil TNI AL that cannot be carried out properly and the assessment system that is implemented is still very simple. Related to the situation and conditions, according to the researchers, the knowledge and skills of superior / appraisal officers need to be $\begin{array}{ll}\text { improved with a human resource management approach } & \text { (HRM) because improving the quality of }\end{array}$ human resources in the Indonesian Navy is a fact that must exist and be carried out with a plan, intensive, focused and affective, and an efficient development process. Therefore, the program of Dapen Persmil TNI $\mathrm{AL}$ which is an assessment of the performance and behavior of TNI AL officers is a structured formal interaction between subordinates and supervisors. According to (Faseeh ullah khan, 2013: 68), performance and behavior assessment programs which are usually in the form of periodic interviews can be held annually or semi-annually.

\section{Recommendation}

In order to increase awareness of the importance of the Navy officers' assessment activity program by referring to the Zero-Based Behavior Abuse Program (ZEBAP), namely achieving a reduction in the number of zero-based violations of the Navy Officers Personnel related to behavioral problems is in the following way: (1). Implement Human Resources Information System (HRIS) „, (2). Establish the Standard Operating Procedures (SOP) of the Indonesian Navy Military Personnel, (3). Implement Monitoring and Evaluation (MONEV) based on Information and Communication Technologies (ICT), namely the Dash Board., Navy Personnel Officers, and (4). implement the Continuous Behavior Improvement Program - (CBIP). Navy Officer Personnel Dash Board Personnel is a HRIS software that contains comprehensive Officer Data after the Navy Navy Dapen program includes: Moral Attitudes, Dedication Attitudes, Discipline Attitudes, Loyalty Attitudes, Honesty Attitudes, Military Attitudes, Responsibility Attitudes, and Leadership

\section{Reference}

[1.] Aguas, Pedro P.; Zapata, Liliana Valle; \& Arellano, Danilsa Lorduy. (2017). Transformational Leadership Plans. World Journal of Education Vol. 7, No. 4; 2017 doi:10.5430/wje.v7n4p1 URL: https://doi.org/10.5430/wje.v7n4p1 https://files.eric.ed.gov/fulltext/EJ1157385.pdf (Diakses 10 Februari 2020)

[2.] Agustiono, Wahyudi . (2018). DEVELOPMENT OF APPRAISAL SYSTEM TO IMPROVE MILITARY OFFICERS PERFORMANCE ASSESSMENT PROCESS. International Journal of ASRO Volume 9, Number 2, pp. 18-32 July-December 2018. http://asrojournalsttal.ac.id/index.php/ASRO/article/view/75/64. (Diakses 12 Februari 2020)

[3.] Ahim, S. (2016). Efektifitas Pembelajaran Pola Pendidikan Sistem Ganda. Bandung.Alfabeta.

[4.] Ahammad, Taslim. (2017). Personnel Management to Human Resource Management (HRM): How HRM Functions? Journal of Modern Accounting and Auditing, September 2017, Vol. 13, No. 9, 412-420 doi: $10.17265 / 1548-6583 / 2017.09 .004$ file:///C:/Users/user/Downloads/Personnel_Management_to_Human_Resource_Management_.pdf. Diakses 20 Oktober 2019

[5.] Alia, Norlina M.; Janggaa ,Rohani; Ismaila, Mazlina; Kamala, Siti Nuur-Ila Mat and Ali , Mohammad Nazri (2015). Influence Of Leadership Styles In Creating Quality Work Culture. INTERNATIONAL ACCOUNTING AND BUSINESS CONFERENCE 2015, IABC 2015 Procedia Economics and Finance $31 \quad\left(\begin{array}{lllll}2015 & & 161 & - & 169\end{array}\right.$ https://core.ac.uk/download/pdf/82548212.pdf(Diakses 10 Februari 2020)

[6.] ALI, SYED ILIYAS; \& KHATOON, SUEBHA. (2016). IMPLEMENTATION OF TOTAL QUALITY MANAGMENT. International Journal of Emerging Trends in Engineering and Development Issue 6, Vol. 6 (November 2016) Available online on http://www.rspublication.com/ijeted/ijeted_index.htm ISSN 2249-6149 @2016 RS Publication, rspublicationhouse@gmail.com . $\quad$ file:///C:/Users/user/Downloads/ijeted-Issue6Vol.6PP.114119November2016.pdf (Diakses 10 Februari 2020)

[7.] Allison, Michael., \& Kaye, Jude. (2015). Strategic Planning for Nonprofit Organizations A Practical Guide for Dynamic Times Third Edition. New Jersey: John Wiley \& Sons, Inc. Arikunto, S. J. ((2013)). Evaluasi Program Pendidikan. Jakarta: Bumi Aksara 
[8.] Al-jawazneh, Bahjat Eid ; \& Smadi, Ziad Moh'd Ali. (2011). The Behavioral Pattern of Continuous Improvement at the Manufacturing Companies in Al-Hassan Industrial Estate (Jordan) European Journal of Social Sciences;Feb2011, Vol. 19 Issue 2, p233-250. https://www.researchgate.net/publication/289423941. file:///C:/Users/user/ Downloads/TheBehavioralPatternofContinuousImprovementatthe.pdf (Diakses 10 Februari 2020)

[9.] Altma,n Charles J. (2016). The Navy Reserve Officer Training Corps (ROTC) Experience and College Student Persistence. A Dissertation SUBMITTED TO THE FACULTY OF THE UNIVERSITY OF MINNESOTA. https://conservancy.umn.edu/bitstream/ handle/11299/182739/Altman_umn_0130E_17349.pdf?sequence=1 (Diakses 10 Februari 2020)

[10.] Alkin , Marvin C.; and Christie, Christina A. (2019). AN EVALUATION THEORY TREE. https://www.researchgate.net/publication/255592205 (Diakses 10 Februari 2020)

[11.] Al-Qahtani, Norah Dhafer; Alshehri,Sabah Sa'ad; Abd.Aziz, Azrilah. (2015). The impact of Total Quality Management on organizational performance. European Journal of Business and Management www.iiste.org ISSN 2222-1905 (Paper) ISSN 2222-2839 (Online) Vol.7, No.36, 2015 119. t: https://www.researchgate. net/ publication / 294886200 .

[12.] ANTONELLI-PONTI, M., VERSUTI, F. M., \& DA SILVA, J. A. (2018). Teachers' perception about genes and behavior. Estudos de Psicologia (Campinas), 35(4), 421-431. doi:10.1590/198202752018000400009 , https://sci-hub.tw/http://dx. doi.org/ 10.1590/1982-02752018000400009 (Diakses 10 Februari 2020)

[13.] Arikunto, Suharsimi dan Abdul Jabar, Cepi Safrudin (2012). Evaluasi Program Pendidikan. Jakarta: PT Bumi Aksara.

[14.] Armyati, Okviana Eky dan Hariningsih. (2012). Perbedaan Perilaku Seksual Pada Remaja Pria Dan Wanita Obesitas Di Akademi Keperawatan Universitas Muhammadiyah Ponorogo.

[15.] Armstrong, Michael ; and Taylor, Step[hen. (2014). Armstrong's handbook of human resource management practice. Thirteenth edition. pages cm ISBN 978-0-7494-6964-1 - ISBN 978-0-74946965-8 (ebk) 1. Personnel management-Handbooks, manuals, etc. I. Title. II. Title: Handbook of human resource management practice. HF5549.17.A76 2013 658.3-dc23, file:///C:/Users/user/Downloads/Armstrongs\%20Handbook\%20of\%20Human\%20Resource\%20M anagement\%20Practice_1.pdf (Diakses 2 Februari 2020)

[16.] Army Regulation 600-100. (2017). Personnel-General Army Profession and Leadership Policy. Headquarters Department of the Army Washington, DC https://armypubs.army.mil/epubs/DR_pubs/DR_a/pdf/web/ARN3758_AR_600100_FINAL_WEB_pdf (Diakses 2 Februari 2020)

[17.] Aslam, Hassan Danial; Aslam, Mehmood; Ali, Naeem ; \& Habib, Badar . (2013). A Historical View of Human Resource Management Practice: Literature Review . International Journal of Human Resource Studies ISSN 2162-3058 2013, Vol. 3, No. 2 file:///C:/Users/user/Downloads/6254-26660-2-PB.pdf (Diakses 4 Februari 2020)

[18.] Ayob, A. H., \& Morell, J. A. (2016). The historical path of evaluation as reflected in the content of Evaluation and Program Planning. Evaluation and Program Planning, 58, 20-27. doi:10.1016/j.evalprogplan.2016.05.006.

hub.tw/https://doi.org/10.1016/j.evalprogplan.2016.05.006 (Diakses 5 Februari 2020)

[19.] Ayomikun O, Idowu,. (2017) .Effectiveness of Performance Appraisal System and its Effect on Employee Motivation. Nile Journal of Business and Economics http://journal.nileuniversity.edu.ng/index.php/NileJBE/ NileJBE (2017) 5: 15-39 @Copyright by NUN http://dx.doi.org/10.20321/nilejbe.v3i5.88. https://www.researchgate.net/publication/320490099_Effectiveness_of_Performance_Appraisal_S ystem_and_its_Effect_on_Employee_Motivation (Diakses 2 Februari 2020)

[20.] Boon, C., Den Hartog, D. N., \& Lepak, D. P. (2019). A Systematic Review of Human Resource Management Systems and Their Measurement. Journal of Management, 0149206 m31881871. doi:10.1177/0149206318818718. 10.1177\%2F0149206318818718 (Diakses 2 Februari 2020)

[21.] Bruns, Hans-Ju“rgen (2014). HR development in local government: how and why does HR strategy matter in organizational change and development? Published online: 13 May 2014. This article is 
published with open access at Springerlink.com, Institute for Human Resource Management, Leibniz Universita“t Hannover, Hannover, Germany e-mail: bruns@pua.unihannover.de, https://link.springer.com/content/pdf/10.1007/ s40685 -014-0002-z.pdf (Diakses 2 Februari 2020)

[22.] Chang, Douglas J. ; \& Davis, Eldridge L. (2017). THE NAVY'S CURRENT ETHICS STRATEGY AND POTENTIAL METHODS FOR IMPROVEMENT. NAVAL POSTGRADUATE SCHOOL MONTEREY, CALIFORNIA. https://apps.dtic.mil/dtic/tr/fulltext/u2/1053130.pdf (Diakses 20 Maret 2020)

[23.] Cohen, L., Manion, L., \& Morrison, K. (2007). Research methods in education. Sixth edition. 2 Park Square,Milton Park,Abingdon,OxonOX14 4RN. Simultaneously published in the USA and Canada by Routledge 270 Madison Avenue, New York, NY 10016!

[24.] Collin, K., Van der Heijden, B., \& Lewis, P. (2012). Continuing professional development. International Journal of Training and Development, 16(3), 155-163. doi:10.1111/j.14682419.2012.00410.x. http://sci-hub.tw/10.1111/j.1468-2419. 2012. 00410.x. (Diakses 4 Februari 2020)

[25.] Deloitte Global Human Capital Trends. (2019). Leading the social enterprise: Reinvent with a human focus 2019 .. https://www2.deloitte. com/ content/dam/ Deloitte /cz /Documents/humancapital/cz-hc-trends-reinvent-with-human-focus.pdf. (Diakses 2 Februari 2020)

[26.] du Plessis, Andries; Douangphichit; Nalinh; and Dodd, Patrick 92016). HRM in Relation To Employee Motivation and Job Performance in the Hospitality Industry. Journal of International Business Research and Marketing Volume 1, journal homepage: www.researchleap.comDOI: 10.18775/jibrm.1849-8558.2015.14.3002 URL: http://dx.doi.org/10.18775/jibrm.18498558.2015.14.3002 , http://researchleap.com/wp-content/uploads/2016/07/HRM-in-Relation-ToEmployee-Motivation-and-Job-Performance-in-the-Hospitality-Industry.pdf . (Diakses 9 Februari 2020)

[27.] Evans, L. A., \& Bae, K.-H. G. (2018). US Army performance appraisal policy analysis: a simulation optimization approach. The Journal of Defense Modeling and Simulation: Applications, Methodology, Technology, 154851291878796. doi:10.1177/1548512918787969 . https://scihub.tw/https:// doi.org/10.1177\%2F1548512918787969 (Diakses 2 Februari 2020)

[28.] Evans, Lee A. \& Robinson,G. Lee.(2020). Evaluating Our Evaluations Recognizing and Countering Performance Evaluation Pitfalls. MILITARY REVIEW January-February 2020. Army University Press Offices 290 Stimson Ave. Fort Leavenworth,Kansas 66027https://www.armyupress.army.mil/Portals/7/military review/Archives/English/JF-20/Evans Rob-Evals.pdf (Diakses 12 Februari 2020)

[29.] Faseeh ullah khan, Muhammad. (2013). Role of Performance Appraisal System on Employees Motivation. IOSR Journal of Business and Management (IOSR-JBM) e-ISSN: 2278-487X.Volume 8, Issue 4 (Mar. - Apr. 2013), PP 66-83 www.iosrjournals.org www.iosrjournals.org 66 | http://iosrjournals.org/iosr-jbm/papers/Vol8-issue4/H0846683.pdf (Diakses 20 Maret 2020)

[30.] Flick, Uwe; von Kardorff, Ernst; \& Steinke, Ines. (2004). A Companion to Qualitative Research, London: Sage

[31.] Flick, Uwe.(2006). An Introduction To Qualitative Research, 4th Edition. Thousand Oaks, CA: Sage

[32.] Frye, Ann W., \& Hemmer, Paul A. (2012). Program Evaluation Models and Related Theories. AMEE Guide No.67. Medical Teacher 34: 288-299.

[33.] Gill,, Carol; and Meyer, Denny . (2011). The role and impact of HRM policy. International Journal of Organizational Analysis Vol. 19 No. 1, 2011 pp. 5-28 q Emerald Group Publishing Limited 1934-8835 DOI 10.1108/19348831111121286. file:///C:/Users/user/Downloads/The_role_and_impact_of_HRM_policy.pdf (Diakses 4 Februari 2020)

[34.] Guyadeen, D., \& Seasons, M. (2016). Evaluation Theory and Practice: Comparing Program Evaluation and Evaluation in Planning. Journal of Planning Education and Research, 38(1), 98110. doi:10.1177/0739456x16675930 sci-hub.tw/10.1177/0739456X16675930, https://sci- 
hub.tw/https://doi.org/ 10.11 77\% 2F 0739456X16675930(file:///C:/Users/user/Downloads/2614966217-1-SM\% 20(1).pdf

[35.] Houston, James (2004) QUALITY CORRECTIONS https://www.ncjrs.gov/pdffiles1/nij/ Mesko/207983.pdf. (Diakses 9 Februari 2020)

[36.] Ikramina, Fildzah; and Gustomo, Aurik . (2014). ANALYSIS OF TRAINING EVALUATION PROCESS USING KIRKPATRICK'S TRAINING EVALUATION MODEL AT PT. BANK TABUNGAN NEGARA (Persero) Tbk. JOURNAL OF BUSINESS AND MANAGEMENT Vol. 3, No.1, 2014: 102-111 , file:///C:/Users/user/Downloads/1088-2273-1-PB.pdf (Diakses 5 Februari 2020)

[37.] Jalagat, Jr , Revenio C. (2017). Leading and Managing People and Organizational Change: Individual and Organizational Benefits and Its Value on Staff Development. Business, Management and Economics Research ISSN(e): 2412-1770, ISSN(p): 2413-855X Vol. 3, No. 8, pp: 146-150, 2017 URL: http://arpgweb.com/?ic=journal\&journal=8\&info=aims 146 Academic Research Publishing Group . file:///C:/Users/user/Downloads/bmer38146-1501.pdf (Diakses 16 Februari 2020)

[38.] Jagannathan, Shanti; Ra, Sungsup \& Maclean, Rupert (2019). Dominant recent trends impacting on jobs and labor markets - An Overview. International Journal of Training Research, 17:sup1, 111, DOI: 10.1080/14480220.2019.1641292 , http://scihub.tw/https://doi.org/10.1080/14480220.2019.1641292 . (Diakses16 Februari 2020)

[39.] KSAL Laksamana TNI Siwi Sukma Adji. (2019). Perwira TNI AL Dituntut Mampu Menganalisis Pelbagai Ancaman. Kamis 14 November 2019, 18:02 WIB https://mediaindonesia.com/read/detail/271622-perwira-tni-al-dituntut-mampu-menganalisispelbagai-ancaman (Diakses 21 Maret 2020)

[40.] Larson,Gerald E.; \& Rimland, Bernard . (1984). PERFORMANCE EVALUATION SYSTEMS: LESSONS LEARNED FROM EXPERIENCE . NPRDC TR 85-6 November 1984 Navy Personnel Research and Development Center San Diego, California 92152-6800. https://apps.dtic.mil/dtic/tr/fulltext/u2/a147907.pdf (Diakses 12 Februari 2020)

[41.] Mabes TNI AL. (2018). Laporan Permasalah Personel TNI AL tahun 2016 sd 2018, Rapat Koordinasi Personel TNI AL, Cilangkap.

[42.] Muryadi, Agustanico Dwi . (2017). Model Evaluasi Program Dalam Penelitian Evaluasi . Jurnal Ilmiah PENJAS, ISSN : $2442-3874 \quad$ Vol.3 $\quad$ No.1, Januari 2017. file:///C:/Users/user/Downloads/538-Article\%20Text-1049-1-10-20170822\%20(2). pdf （Diakses 24 Februari 2020)

[43.] Munthe, Ashiong P.(2015). PENTINGYA EVALUASI PROGRAM DI INSTITUSI PENDIDIKAN: Sebuah Pengantar, Pengertian, Tujuan dan Manfaat1 . file:///C:/Users/user/Downloads/13Article\%20Text-26-1-10-20151208.pdf (Diakses 24 Februari 2020)

[44.] Mwaniki, Rose; \& Gathenya, Jane (2015). Role of Human Resource Management Functions On Organizational Performance with reference to Kenya Power \& Lighting Company - Nairobi West Region. International Journal of Academic Research in Business and Social Sciences April 2015, $\begin{array}{lllll}\text { Vol. } & 5, & \text { No. } & 4 & \text { ISSN: }\end{array}$ http://hrmars.com/hrmars_papers/Role_of_Human_Resource_Management_Functions_On_Organi zational_Performance_with_reference_to_Kenya_Power_Lighting_Company_\%E2\%80\%93_Nair obi_West_Region.pdf (Diakses 3 Februari 2020)

[45.] Narang, Gurdeep Singh. (2016). Relevance of Best Human Resource Practices for the Armed Forces. Arabian Journal of Business and ar A Management Review 2016, 6:4 DOI: 10.4172/22235833.1000232 . https://www.hilarispublisher.com/open-access /relevance-of-best-human-resourcepractices-for-the-armed-forces-2223-5833-1000232.pdf (Diakses 3 Februari 2020)

[46.] NAVY PERSONNEL COMMAND. (2019). Performance Evaluation. 5720 Integrity Drive, Millington TN 38055-0000 . This is an official U.S. Navy Website Last Modified: 10/4/2019 12:12

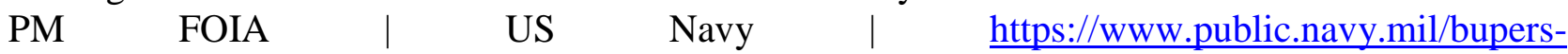
npc/career/performanceevaluation/Pages/ default.aspx (Diakses 12 Februari 2020)

[47.] Nurhayati, Yetti. (2018). PENERAPAN MODEL KIRKPATRICK UNTUK EVALUASI PROGRAM DIKLAT TEKNIS SUBTANTIF MATERI PERENCANAAN PEMBELAJARAN DI 
WILAYAH KERJA PROVINSI KEPULAUAN RIAU. Andragogi Jurnal Diklat Teknis 1708 Volume: VI No. 2 Juli - Desember 2018. file://D:/AIJ\%20\%23\%2097\%20(KIRKPATRICK).pdf ((Diakses 22 Februari 2020)Okoye, P.V.C. and Ezejiofor, Raymond A. . (2013). The Effect of Human Resources Development on Organizational Productivity. International Journal of Academic Research in Business and Social Sciences October 2013, Vol. 3, No. 10 ISSN: 22226990.http://hrmars.com/hrmars_papers/The_Effect_of_Human_Resources__ Develop ment_on_Organizational_Productivity.pdf (Diakses 3 Februari 2020)

[48.] Paine, Lynn S. (2020). Managing for Organizational Integrity. Harvard Business Review. https://hbr.org/1994/03/managing-for-organizational-integrity (Diakses 18 Maret 2020)

[49.] Patrichi, Marius Emil. (2015). GENERAL MILITARY HUMAN RESOURCE MANAGEMENT AND SPECIAL FORCES HUMAN RESOURCE MANAGEMENT. A COMPARATIVE OUTLOOK. Journal of Defense Resources Management Vol.6 Issue 2 (11)/ 2015 http://journal.dresmara. ro/ issues/volume6_issue2/09_patrichi.pdf (Diakses 3 Februari 2020)

[50.] Peraturan Presiden (Perpres) Nomor 66 tahun 2019 tentang Susunan Organisasi Tentara Nasional Indonesia https://sipuu.setkab.go.id /PUUdoc/175973/ Perpres_Nomor_66_Tahun_2019.pdf (Diakses 2 Februari 2020)

[51.] Peraturan Pemerintah Nomor 39 TAHUN 2010 Tentang , \& 39. (2010). Administrasi Prajurit TNI.

[52.] Peraturan Kepala Staf Angkatan Laut Nomor Perkasal/1/V/2003 tentang Petunjuk Teknis Penilaian Personel TNI AL.

[53.] Peraturan Panglima TNI Nomor Perpang/59/X/2008 tentang Tentang Petunjuk Adminitsrasi Penggunaan Prajurit TNI.

[54.] Philips, Jack J., Stone, Ron Drew (2000). How To Measure Training Results. New Work: McGraw-Hill Companies.

[55.] Pourhanifeh, Gholam Hassan; and Mazdeh, Mohammad Mahdavi. (2016). Identifying the critical success factors of organization with Analytic Hierarchy Process approach (case study - Iran Argham Company). Problems and Perspectives in Management, 14(4), 54-60. doi:10.21511/ppm.14(4).2016.06. $\quad$ https://businessperspectives.org/ images/pdf/applications/publishing/templates/article/assets/8020/PPM_2016_04_Pourhanifeh.pdf ((Diakses 24 Februari 2020)

[56.] Prayoga, Immanuel Teguh. (2011). Strategi Dinas Perhubungan Kota Surakarta Dalam Optimalisasi Alat Pemberi Isyarat Lalu Lintas Berbasis Intellegent Transport System (APILL-ITS). Administrasi Negara. Fakultas Ilmu Sosial dan Ilmu Politik. Universitas Sebelas Maret. Surakarta. file:///C:/Users/user/Downloads/Immanuel \%20Teguh\% 20Prayoga\%20(1).pdf. (Diakses 12 Februari 2020)

[57.] Rafiei, N., \& Davari, F. (2015). The Role of Human Resources Management on Enhancing the Teaching Skills of Faculty Members . Materia Socio Medica, 27(1), 35. doi:10.5455/msm.2014.27.35-38 https://sci-hub.tw/https:// dx.doi. org/10.5455\%2 Fmsm.2014.27.35-38 (Diakses 5 Februari 2020)

[58.] Rahman, Hasreena Abdul; \& Jamil Ahmad. (2015) Conceptual Framework For Evaluating Professional Upskilling Of English Language Teachers Programme., Australian Journal of Basic and Applied Sciences, 9(14) Special 2015, Pages: 93-99, http://www.ajbasweb.com/old/ajbas/2015/Special\% $20 \quad$ MPCN\%20LANGKAWI/93-99.pdf (Diakses 2 Februari 2020)

[59.] Rosana, Ellya.(2014). KEPATUHAN HUKUM SEBAGAI WUJUD KESADARAN HUKUM MASYARAKAT. Jurnal TAPIs Vol.10 No.1 Januari-Juni , file:///C:/Users/user/Downloads/16003165-1-SM.pdf. Diakses 31 Oktober 2019

[60.] Rudes, Danielle S.; Viglione, Jill ; \& Porter, Courtney M. (2014). Using Quality Improvement Models in Correctional Organizations Volume 77 Number 2. file://C:/Users/user/Downloads/Rudes-Viglione-Porter--QualityImprovement ModelsinCorrecitons--2013.pdf. dIAKSES 5 nOVEMBER 2019

[61.] Rus, M., \& Sandu, M. (2013). Personality Factors and Job Satisfaction Levels in Military Staff Employed on a Contract basis. Procedia - Social and Behavioral Sciences, 92, 814-819. 
doi:10.1016/j.sbspro.2013.08.759

sci-hub.tw/10.1016/j.sbspro.2013.08.759

$\underline{\text { https://sci- }}$

hub.tw/https://doi.org/ 10. 1016/j.sbspro.2013.08.759 (Diakses 11 Februari 2020)

[62.] Sadeghifar, J., Jafari, M., Tofighi, S., Ravaghi, H., \& Maleki, M. R. (2014). Strategic Planning, Implementation, and Evaluation Processes in Hospital Systems: A Survey From Iran. Global Journal of Health Science, 7(2). doi:10.5539/gjhs.v7n2p56. https://scihub.tw/https://dx.doi.org/10.5539\% 2F gihs.v7n2p56 (Diakses 9 Februari 2020)

[63.] Saeed, F.; Bury, A.; Bonsall, S.; \& Riahi, R. (2016). A Cost Benefit Analysis Approach to Identify Improvements in Merchant Navy Deck Officers' HELM (Human Element Leadership and Management) Training. The International Journal on Marine Navigation and Safety of Sea Transportation Volume 10 Number 4 December 2016 DOI : 10.12716/1001.10.04.02 http://www.transnav.eu/Article_A_Cost_Benefit__Analysis_Approach_Saeed,40,677.html (Diakses 12 Februari 2020)

[64.] Saha, Nibedita; Chatterjee, Bani; Gregar,Aleš; \& Sáha, Petr. (2016). The impact of SHRM on sustainable organizational learning and performance development. International Journal of Organizational Leadership 5 63-75, file:///C:/Users/user/Downloads/IJOL-2015-17.pdf. Diakses 20 Oktober 2019

[65.] Santoso, R. (2017). Tekhnik Penuli9san Laporan Penelitian Kwalitatif . Jakarta: LPSP3.

[66.] Sevel, Michael, (2018). Obeying the Law. The University of Sydney Law School Legal Studies Research Paper Series No. 18/45 August, file:///C:/Users/user/Downloads/SSRN-id3226760.pdf. Diakses 31 Oktober 2019

[67.] Silva, M. S. A. e, \& Lima, C. G. da S. (2018). The Role of Information Systems in Human Resource Management. Management of Information Systems. doi:10.5772/intechopen.79294 https://sci-hub.tw/10.5772/intechopen.79294 (Diakses 20 Maret 2020)

[68.] Sugiyono (2013). Metode Penelitian Kuantitatif, Kualitatif dan R\&D. Bandung: Alfabeta, cet ke19

[69.] Tan, C, L and Nasurdin, A, M. (2011). Human Resource Management Practices and Organizational Innovation : Assessing the Mediating Role of Knowledge Management Effectiveness. Volume 9 Issue 2, ISSN 1479-4411 (CAcademic Publishing International Ltd Reference this paper as: - available online at www.ejkm.com,file:///C:/Users/user/Downloads/ejkm-volume9-issue2-article $\quad 289 \% \quad$ 20(2).pdf (Diakses 2 Februari 2020)

[70.] Ulum, I. (2016). Intellectual Capital: Model Pengukuran, Framework Pengungkapan, dan Kinerja Organisasi. No. ISBN978-979-796-157-2. Malang, Indonesia: Ummpress

[71.] UNDANG-UNDANG REPUBLIK INDONESIA NOMOR 34 TAHUN 2004 TENTANG TENTARA NASIONAL INDONESIA, http://www.dpr.go.id/dokblog/dokumen/ F_ 20150616_4 760.PDF. (Diakses 2 Februari 2020)

[72.] Undang-Undang Republik Indonesia Nomor 34 Tahun 2004 Tentang Tentara Nasional Indonesia

[73.] UNITED NATIONS OFFICE ON DRUGS AND CRIME (UNODC). (2017). "Making Indonesia safer from crime, drugs and terrorism" Country Programme for Indonesia 2017-2020. https://www.unodc.org/documents/indonesia/publication/2017/UNODC

Country_Programme_2017___2020.pdf. (Diakses 20 Maret 2020)

[74.] United Nations. (2017). Evaluation-based analysis of good practices in UNODC's approach to capacity building Independent Evaluation Unit (IEU) September Vienna. https://www.unodc.org/documents/evaluation/Knowledge-Products/ $\quad$ UNODC_IEU_ Evaluationbased_Capacity_Building_Analysis_final_October_2017.pdf. (Diakses 20 Maret 2020)

[75.] Václav, Oškrdal; Antonín, Pavlíček; \& Petra, Jelínková. (2011). Processes, Performance Drivers and ICT Tools in Human Resources Management Journal of Competitiveness | Issue 2/2011. https://www.cjournal.cz/files/58.pdf (Diakses 20 Maret 2020)

[76.] Visi dan Misi Tentara Nasional Indonesia Angkatan Laut https://www.tnial.mil.id/visimisi/ (Diakses 22 Februari 2020)

[77.] Wholey, J. S., H. P. Hatry, \& K. E. Newcomer (2010). Handbook of practical eavaluation program. San Francisco: Jossey-Bass. Third edition.

[78.] Widoyoko, Eko P. (2016). Evaluasi Program Pembelajaran . Yogyakarta: Pustaka Pelajar. 
[79.] Widodo, S. E. (2015). Manajemen Pengembangan Sumber Daya Manusia. Yogyakarta: Pustaka Pelajar.

[80.] Wirawan. (2016). Evaluasi Teori, Model, Metodelogi, Standar, Aplikasi dan Profesi . Jakarta : PT Raja Grafindo Persada. 